\title{
MODEL MISI PERKOTAAN RASUL PAULUS DI KORINTUS
}

\author{
Jonar Situmorang
}

\section{PENDAHULUAN}

Misi merupakan pesan Allah kepada umat-Nya, khususnya orang-orang percaya dan yang terpanggil dalam pekerjaan-Nya yang mulia, yaitu mengabarkan Kabar Baik (Injil). Karena itu, gereja harus berperan serta dalam panggilan tersebut. Yang dimaksud gereja disini adalah orang-orang percaya (ekklesia), dan termasuk juga gereja sebagai suatu lembaga.

Ada pembelajaran yang sangat berharga sehubungan dengan pelayanan misi, yaitu lewat pelayanan misi yang dilakukan rasul Paulus. Begitu banyak tempat yang dilalui rasul Paulus sehingga dikenal dengan perjalanan misinya sampai tiga tahap/periode, secara khusus di kota Korintus. Rasul Paulus melakukan kunjungan dari satu kota ke kota lain, sehingga dapat disebut sebagai model misi perkotaan, menjadi cerminan bagi gereja Tuhan dalam pelayanan misi di kota.

Korintus dikenal sebagai kota maksiat yang penuh dengan penyembahan berhala dan perbuatan mesum. Namun di tengah keadaan itu, rasul Paulus dapat melakukan pendekatan sehingga di daerah ini boleh berdiri jemaat Kristus. Salah satu pendekatan yang dilakukan adalah secara kontekstualisasi. Hal ini terlihat dalam suratnya dalam 1 Korintus 9:19-22, yang penekanannya adalah "menjadi seperti". Kata menjadi seperti inilah sebagai langkah dan upayanya dalam pelayanan misi sehingga bisa diterima oleh orang Korintus.

"Menjadi seperti", bukan berarti harus kompromi. Jika memang tidak sesuai dengan Injil dalam suatu budaya atau kebiasaan dari suatu daerah, tentu harus ditolak. Yang dilakukan Paulus adalah mencoba mendekati orang-orang di Korintus, sehingga masuklah berita Injil ke daerah itu. Jemaat yang sudah berdiri di sana, diingatkan supaya jangan terjebak dengan pergaulan yang buruk, karena hal itu akan merusak kebiasaan yang baik (1Kor. 15:33).

\section{Misi Perkotaan Rasul Paulus}

Pada bagian ini dimulai dengan pembahasan akan Misi Dalam Alkitab. Kemudian menjelaskan akan Kisah Panggilan dan Perjalanan Hidup Rasul Paulus. Selanjutnya adalah Misi Perkotaan Rasul Paulus.

Misi Dalam Alkitab

Bagian ini membahas akan Misi Dalam Perjanjian Lama dan Misi Dalam Perjanjian Baru. 


\section{Misi Dalam Perjanjian Lama}

Dalam teologi Kitab Suci Perjanjian Lama (PL), konsep misi merupakan sebuah konsep marginal. Bisa misi dipahami sebagai misi untuk pewartaan di tempat-tempat yang jauh maka menjadi agak sulit memahami konsep itu dalam alam pemikiran PL. Tidak ada indikasi kuat dalam PL yang memperlihatkan bahwa orang beriman diutus oleh Allah (Yahweh) keluar dari batas-batas geografis Israel maupun kultur Yahudinya untuk menjadikan orang lain percaya pada Yahweh. Tidak ada cukup banyak bukti yang memperlihatkan bahwa kegiatan di luar batas Israel untuk menjadikan orang-orang di wilayah itu beriman kepada Allah.

Teologi misi dalam Perjanjian Lama akan selalu bergerak dalam dialektika antara identitas dan universalitas. Orang Israel terbuka menerima orang-orang kafir yang takut akan Allah, yakni mereka yang bertobat ke dalam lingkungan Yahudi akan diterima tetapi pada saat yang sama orang Yahudi sendiri tidak menyebarkan agamanya dengan maksud untuk mempertobatkan mereka. Dalam konsep itu orang kafir dapat masuk dan menjadi bagian dalam umat pilihan tetapi orang Israel tidak merasa dirinya diutus kepada orang-orang kafir. ${ }^{1}$

Allah Perjanjian Lama yang mengabarkan Injil melanjutkan karya penyelamatanNya melalui anak-Nya dan gereja-Nya dengan kuasa Roh Kudus. Tema mengenai pengkabaran Injil semakin meningkat dalam Perjanjian Baru, "Misi pertama adalah milik Allah, karena Dialah yang mengutus nabi-nabi-Nya, Anak-Nya, Roh-Nya. Dari antara misi-misi ini, misi Anak Allah merupakan pusat, karena misi Anak Allah merupakan puncak dari pelayanan nabi-nabi, dan dalam misi ini tercakup pengutusan Roh Kudus sebagai klimaknya.

Salah satu contoh pembelajaran akan pelayanan misi dalam Perjanjian Lama adalah panggilan misi yang diterima Yunus dari Tuhan untuk pergi ke Niniwe. Ada pembelajaran berharga yang dapat dipetik sehubungan dengan misi perkotaan. Pertama, Allah yang Mahakudus memiliki kepedulian terhadap penduduk kota yang tidak kudus. Kedua, nabi Yunus mewakili banyak orang percaya yang tidak berani melayani kota yang jahat. Ketiga, Yunus mewakili Israel, umat pilihan TUHAN, yang menjadi saluran berkat TUHAN bagi bangsa-bangsa lain. Keempat, kegagalan melayani kota adalah kegagalan melayani seluruh bangsa. Kelima, Tuhan berbicara kepada Yunus tentang hakikat pelayanan perkotaan yaitu melayani orang-orang yang berdosa di kota. Ada suatu pengharapan Yunus terhadap kota yang terhukum supaya menerima keselamatan dari Allah.

\section{Misi Dalam Perjanjian Baru}

Berita Perjanjian Baru adalah bahwa Allah Perjanjian Lama yang mengabarkan Injil itu telah datang, dalam rupa seorang manusia, sehingga Ia dapat memberikan keselamatan kepada ciptaan yang dahulu memilih untuk tidak taat kepada-Nya. Tetapi ada lebih dari itu. Kepada mereka yang menerima keselamatan dari Penebus Ilahi yang

\footnotetext{
${ }^{1}$ Paulus Yan Olla, Dipanggil Menjadi Saksi Kasih, (Yogyakarta: Kanisius, 2008), 24-25
} 
diutus Allah, diberikan satu tugas untuk mengabarkan berita itu keseluruh dunia. Misi dalam Perjanjian Baru bersifat sentrifugal (dari pusat ke luar), yang berarti bahwa dari gereja atau dari Israel kabar keselamatan akan disampaikan kepada semua suku-suku bangsa. $^{2}$

Berbeda dengan misi yang dilakukan Yesus Kristus ketika berada di muka bumi ini. Misi yang dilakukan-Nya bersifat inklusif, karena merangkul semua orang atau semua kalangan. Itulah sebabnya Yesus memberi amanat untuk menjadikan semua bangsa menjadi murid-Nya (Kis. 28:18), supaya setiap lutut bertelut dan setiap lidah mengaku bahwa Yesus adalah Raja di atas segala raja dan Juruselamat atas dunia ini.

Amanat Agung adalah pokok dan penting dalam kekristenan. Dikatakan demikian karena semua kitab Injil dan Kisah Para Rasul menuliskan tentang itu. Jadi fokus Amanat Agung terletak dalam penginjilan dan pemuridan, sasarannya adalah seluruh bangsa dapat memperoleh keselamatan di dalam Tuhan Yesus Kristus (2Kor. 3:18). Dengan bercermin dari misi yang dilakukan Yesus inilah, rasul Paulus melakukan model misi, yang menembus berbagai suku bangsa.

Amanat Agung yang disebutkan dalam Matius 28:19 menjadi kunci untuk memahami akan pesan Yesus dalam memuridkan, yaitu mengajar dan membaptis. Dari dua aspek tersebut, mengajar tampaknya lebih menjadi perhatian Matius daripada daripada membaptis. Setidaknya ia tampak dari penggunaan kosa kata "baptis" yang muncul 7 kali dalam 2 atau setidaknya dalam 3 peristiwa, sementara kata "mengajar" muncul 14 kali dalam 12 peristiwa. $^{3}$

Dalam Kisah Para Rasul 1:8 merupakan ayat yang menjelaskan supaya kita menjadi saksi yang dapat melintasi dari berbagai lapisan masyarakat, sampai akhirnya bisa menjadi saksi bagi dunia. Kata kunci dari ayat tersebut adalah Roh Kudus, kuasa, dan saksi-Ku. Orang percaya dapat memiliki kuasa hanya jika Roh Kudus turun ke atasnya. Tujuan pemberian kuasa tersebut bukan untuk disombongkan, tetapi sematamata hanya untuk menjadi saksi bagi Yesus Kristus. Itulah prinsip rohani yang paling mendasar yang menjiwai seluruh kisah pelayanan para rasul.

Kuasa yang dimaksudkan Tuhan Yesus adalah kuasa untuk mengalami perubahan hidup. Ishak Sugianto menyebutnya dengan istilah transforming, yang berasal dari kata to transform (bahasa Inggris) yang berarti mengubah. Transforming Power of the Holy Spirit adalah kuasa Roh Kudus yang membawa perubahan sangat nyata dalam hidup manusia. Tuhan Yesus memiliki kuasa untuk mengubahkan hidup seseorang. ${ }^{4}$ Yang terpening dalam melakukan pelayanan misi ini adalah penyertaan dan pengurapan kuasa Roh Kudus.

\footnotetext{
2 Adrianus Pasasa, Misi Penginjilan (2 Februari 2012, sumber: http://a31misipenginjilan.blogspot.co.id/2012/02/dasar-alkitab-tentang-misi-dalam.html), dikutip pada 3 Nopember 2017 23

${ }^{3}$ Pelita Hati surbakti, Yang Terutama Dalam Amanat Agung, (Jakarta: BPK Gunung Mulia, 2017),

${ }^{4}$ Ishak Sugianto, The Transforming Power of the Holy Spirit, (Yogyakarta: ANDI, 2009), 16
} 
Dengan mengutip Stott, Graham mengingatkan kita supaya jangan menjadi orang Kristen kelinci. Orang Kristen kelinci adalah orang Kristen yang hanya berkumpul dengan orang-orang Kristen lainnya; mereka tidak menjangkau jiwa-jiwa yang masih tersesat. ${ }^{5}$ Tetapi, dalam menjangkau jiwa-jiwa juga perlu suatu pertimbangan. Misalnya, dengan mengutip Stott, Felix Liu menulis, "Bila kita dapat memenangkan kepercayaan dan persahabatan mereka terlebih dahulu, tidak sulit memenangkan mereka." Sebelum memenangkan kepercayaan mereka, janganlah sembarangan melakukan pembicaraan mengenai Injil. Persahabatan merupakan azas Injil. ${ }^{6}$

\section{Panggilan dan Perjalanan Hidup Rasul Paulus}

Untuk mengenal akan ketokohan rasul Paulus, akan dikisahkan perjalanan hidupnya. Pada bagian ini mengetengahkan tiga hal, yaitu: Panggilan Rasul Paulus, Perjalanan Misi Rasul Paulus, Akhir Hidup Rasul Paulus.

\section{Panggilan Rasul Paulus}

Sekilas melihat akan biografi Rasul Paulus. Paulus berarti: orang yang kecil, sedikit. Ini merupakan nama dalam bahasa Yunani. Ada dua masa yang berbeda dalam kehidupan Paulus, yaitu masa kanak-kanak yang dihabiskan di Tarsus, dan masa muda serta awal kedewasaan di Yerusalem. Ia dididik pertama-tama di sekolah-sekolah Tarsus, yang merupakan Atena kecil untuk tempat belajar. Di sana ia mempelajari filsafat dan puisi orang-orang Yunani. Dari sana ia dikirim ke sekolah tinggi di Yerusalem, untuk mempelajari ilmu ketuhanan dan hukum Yahudi. Gurunya adalah Gamaliel, seorang Farisi terkemuka. ${ }^{7}$

Dilahirkan di Tarsus di wilayah Kilikia (Kis. 9:11; 21:39; 22:3) dan tinggal di sana. Kilikia adalah daerah yang terletak di luar wilayah Palestina. Tarsus adalah sebuah kota perdagangan yang ramai dan kota tempat studi filsafat dan budaya, di negeri yang dulu disebut Sisilia tetapi sekarang disebut Turki. Mayoritas penduduk di kota tersebut adalah orang-orang Yunani. Tarsus pada masa itu merupakan sebuah pelabuhan internasional. Perdagangan internasional juga berkembang pesat di sana. Orang Yunani, orang Timur, orang Yahudi dan juga kaum nomaden hidup berdampingan dalam kebebasan penuh. Orang-orang Yahudi di Tarsus juga banyak. Mereka hidup dengan bebas dan tidak hidup dalam ghetto sebagaimana biasanya. ${ }^{8}$

Di kota Yunani itu memang banyak orang-orang Yahudi perantau. Sekalipun perantau dan tinggal di kota kebudayaan Yunani, mereka tetap taat pada iman leluhur mereka tanpa harus tinggal sebagai kelompok tertutup. Dalam keluarganya tentu saja ia dididik dalam agama Yahudi sehingga ia menjadi seorang Yahudi yang taat. Kehidupannya sebagai anak kota juga turut mempengaruhi pengajarannya. ${ }^{9}$ Di bidang

\footnotetext{
${ }^{5}$ Billy Graham \& Rebecca Manley Pippert, Andalah Saksi-Nya, (Bandung: LLB, 1995), 91-92

${ }^{6}$ Felix Liu, P.I. Pribadi, (Malang: SAAT, 1992), 45

${ }^{7}$ Matthew Henry, Kisah Para Rasul, (Surabaya: Momentum, 2014), 354

${ }^{8}$ Eko Riyadi Pr., Hidup Dalam Kristus, (Yogyakarta: Kanasius, 2008), 23

${ }^{9}$ Y.M. Seto Marsuni, Paulus Sukacita Rasul Kristus, (Yogyakarta: Kanisius, 2008), 15
} 
agama, ia menjadi aktivis Farisi yang membina iman orang-orang Yahudi di Tarsus dan sekitarnya. Untuk melaksanakan tugas itu, ia pasti berusaha untuk menguasai kitab-kitab suci Yahudi.

Kedua orangtua Saul tetap beragama Yahudi, tetapi lebih fasih berbahasa Yunani, dan memiliki kewarganegaraan Romawi (barangkali karena bekerja untuk birokrasi di bawah pemerintahan Romawi). Pada saat itu orang-orang yang memiliki kewarganegaraan Romawi memperoleh beberapa hak sipil seperti orang-orang keturunan Romawi, misalnya di bidang pengadilan berhak naik banding sampai Mahkama Agama di Roma. ${ }^{10}$

Kewarganegaraan Romawi ini memainkan peran penting dalam konflik yang dialaminya dengan para penguasa lokal tempat ia mewartakan Injil (Kis. 16:37; 22:28; 2.5:10). Berasal dari suku Benyamin, seorang dari golongan Farisi dan juga memiliki warga negara Roma dari sejak lahir (Kis. 16:21, 37-38; 22:25-29; Fil. 3:5). Karena itulah kemungkinan orangtuanya memberi nama Saul padanya, sesuai dengan raja pertama bagi bangsa Israel dari keturunan suku Benyamin. Sejak kecil Saul sudah disunat, sebagai tanda bahwa ia sudah dimasukkan ke dalam lingkungan iman Abraham, lalu dididik dalam agama Yahudi, baik di rumah sendiri maupun di sinagoge dan di sekolah khusus untuk anak-anak Yahudi. Paulus fasih berbahasa Yunani dan mampu memahami kitab-kitab agama Yahudi yang ditulis dalam bahasa Ibrani. Karena kecerdasannya maupun karena kemampuan finansial orangtuanya, Saul kemudian melanjutkan studi di bidang agama Yahudi di Yerusalem, di bawah bimbingan para rabbi yang mahir, misalnya Gamaliel. ${ }^{11}$

Ayah dan ibunya sama-sama orang Yahudi asli. Oleh sebab itulah ia menyebut dirinya orang Ibrani asli. Kata "dibesarkan" dalam Kisah Para Rasul 22:3 dapat berarti ketika masih bayi Paulus pindah dari Tarsus ke Yerusalem. Tetapi kebanyakan para ahli berpendapat hal itu mengacu hanya pada pendidikannya. ${ }^{12}$

Paulus seorang Yahudi asli dan seorang Yahudi yang bangga atas keyahudiannya (bnd. Rom. 9:1-5). Ia tidak pernah menyembunyikan asal-usulnya. Paulus seorang Yahudi dari diaspora, perantauan. Itu cukup jelas bila orang membaca bahasa Yunaninya dan gaya sastra surat-suratnya. Karena Paulus seorang Yahudi asli dan dari golongan Farisi, sehingga ia dikenal sebagai orang yang fanatik, yang membuatnya seorang pembenci yang tidak ada taranya, yang menyebabkan bahwa ia tidak saja mau menangkap pengikut-pengikut Yesus, tetapi juga membunuhnya.

Paulus adalah seorang Yahudi dari Tarsus (Kis. 21:29; 22:3), dan ia bangga akan hal ini. Lelaki yang dilahirkan di Tarsus ini akan membanggakan diri dengan mengutip ucapan Xenofo, "Tarsus kota besar dan bersemarak." Pada waktu dihadapkan pada panglima Yerusalem, panglima Yerusalem itu keheran-heranan. Mengapa? Semula dia mengira bahwa Paulus hanyalah seorang penghasut, keturunan Mesir; tetapi ternyata dia

\footnotetext{
${ }^{10}$ Purwa Hadiwardoyo, Warisan Paulus Bagi Umat, (Yogyakarta: Kanisius, 2008), 12

${ }^{11}$ Al. Purwa Hadiwardoyo, Warisan Paulus Bagi Umat ..., 12-13

12 John Drane, Memahami Perjanjian Baru, (Jakarta: BPK Gunung Mulia, 1996), 289
} 
fasih berbicara dalam bahasa Yunan: "Aku seorang Yahudi, warga kota Tarsus di Sisilia, kota bukan sembarang kota" (Kis. 26:39). Kalimat ini diucapkan dengan nada puas. ${ }^{13}$

Dalam suratnya kepada jemaat di Korintus dikatakannya bahwa dia memenuhi syarat untuk menjadi rasul (2Kor. 11:22). Dalam Galatia 1:1 Paulus menjelaskan akan kerasulannya. Dokumen ini (surat Galatia) ditulis sekitar tahun 53 M, tidak lama setelah Paulus mengunjungi Korintus dan dibawa ke hadapan Gubernur Gallio. Pemerintahan Gallio ditempatkan antara tahun 51 - 52 M berdasarkan catatan Romawi dan Kisah Para Rasul 18:12-16, dimana Paulus diadukan kepada Gallio, yang kelihatannya mencatat peristiwa sejarah; memang surat-surat Paulus kepada jemaat di Korintus berlatar belakang bertikaian dan kesulitan. ${ }^{14}$

Ketika dia diadili di depan Sanhedrin, dia berkata, "Aku adalah orang Farisi, keturunan orang Farisi" (Kis. 23:6). Tom Jacob mengatakan bahwa dengan status ini Paulus tidak merasa malu bahwa ia keturunan Yahudi. Justru sebaliknya, ia merasa bangga dan tetap sangat cinta kepada bangsanya sendiri. Kendati demikian rupa-rupanya Paulus melihat peralihannya kepada agama kristiani sebagai suatu "break", bukan hanya suatu perubahan, melainkan suatu "ciptaan baru" (2Kor. 5:17). ${ }^{15}$

Paulus juga seorang warga negara Roma. Dan dia bangga akan hal itu. Waktu dia ditahan di Filipi dan dimasukkan ke dalam penjara, maka para hakim hendak membebaskannya begitu saja, lalu Paulus menolak mentah-mentah. Paulus berkata, "Tanpa diadili mereka telah mendera kami, warganegara-warganegara Roma, di muka umum, lalu melemparkan kami ke dalam penjara. Sekarang mereka mau mengeluarkan kami dengan diam-diam? Tidak mungkin demikian! Biarlah mereka datang sendiri dan membawa kami ke luar" (Kis. 16:37). Ketika dia nyaris disesah di Yerusalem, dia berkata, "Bolehkan kamu menyesah seorang warga negara Roma?" (Kis. 22:25). Sejak panggilannya itulah Paulus dengan gigih memberitakan Injil, walaupun ada banyak tantangan dan ancaman, yang sampai mempertaruhkan nyawa. Akhir hidupnya ia mati syahid, dengan kepalanya dipenggal.

Sebelum mengalami pertobatan, namanya adalah Saulus (yang bunyinya berdekatan dengan Saul), yang berarti: yang diminta demi Allah, atau yang diinginkan. Nama Yunaninya adalah Paulus, yang biasa dipergunakan sebagai nama panggilannya. Dari perubahan namanya ini menunjukkan bahwa ada kerendahan hati pada diri Paulus sesudah ia mengalami pertobatan. Mengapa? Karena, sesudah ditangkap Tuhan Yesus dan menjadi pelayan-Nya, ia merasa dirinya kecil dan tidak ada apa-apanya. Bahkan dalam suratnya, Paulus menulis demikian: "Tetapi apa yang dahulu merupakan keuntungan bagiku, sekarang kuanggap rugi karena Kristus. Malahan segala sesuatu kuanggap rugi, karena pengenalan akan Kristus Yesus, Tuhanku, lebih mulia dari pada semuanya. Oleh karena Dialah aku telah melepaskan semuanya itu dan menganggapnya sampah, supaya aku memperoleh Kristus" (Fil. 3:7-8).

\footnotetext{
${ }^{13}$ A. Brunot SCJ., Paulus dan Pesannya, (Yogyakarta: Kanisius, 1992), 10-11

${ }^{14}$ Bruce Chilton, Studi Perjanjian Baru Bagi Pemula, (Jakarta: BPK Gunung Mulia), 57

${ }^{15}$ Tom Jacobs, Paulus: Hidup, Karya dan Teologinya, (Yogyakarta: Kanisius, 1993), 51-52
} 
Sekitar tahun 160, seorang Kristen dari Asia menulis semacam novel sejarah berjudul "Kisah Paulus", dan di dalamnya ia memberi gambaran: "Dia bertubuh pendek, rambutnya mulai menipis, kakinya agak bengkok, perawakannya kekar, alisnya lebat hingga saling bertemu, hidungnya sedikit lengkung, dan tindak tanduknya anggun; kadang-kadang ia nampak sebagai manusia, dan kadang-kadang wajahnya mirip seorang malaikat." Dengan mengutip salah satu penulis kuno, Henry menyebutnya Homo tricubitalis - hanya setinggi $135 \mathrm{~cm} .^{16}$

Berbicara tentang penginjilan, perlu belajar banyak pada rasul Paulus, yang mempunyai komitmen yang tegas, "Celakalah aku, jika aku tidak memberitakan Injil" (1Kor. 9:13). Tidak ada alasan baginya untuk menolak pemberitaan Injil. Paulus merasa berhutang nyawa pada dirinya karena sudah menerima keselamatan secara pribadi atas perjumpaannya dengan Tuhan Yesus ketika menuju perjalanan ke kota Damsyik. Seharusnya ia binasa atas perbuatannya yang sungguh biadab dengan membunuh para pengikut Kristus atau pengikut Jalan Tuhan.

Atas kemurahan Tuhan, Rasul Paulus masih diberi kesempatan untuk hidup dan melayani pekerjaan Tuhan. Lebih lengkapnya, di sini dikutip akan panggilan Rasul Paulus dalam melayani untuk memberitakan Injil dalam Kisah Para Rasul 9:1-22:

Sementara itu berkobar-kobar hati Saulus untuk mengancam dan membunuh murid-murid Tuhan. Ia menghadap Imam Besar, dan meminta surat kuasa dari padanya untuk dibawa kepada majelis-majelis Yahudi di Damsyik, supaya, jika ia menemukan laki-laki atau perempuan yang mengikuti Jalan Tuhan, ia menangkap mereka dan membawa mereka ke Yerusalem. Dalam perjalanannya ke Damsyik, ketika ia sudah dekat kota itu, tiba-tiba cahaya memancar dari langit mengelilingi dia. Ia rebah ke tanah dan kedengaranlah olehnya suatu suara yang berkata kepadanya: "Saulus, Saulus, mengapakah engkau menganiaya Aku?" Jawab Saulus: "Siapakah Engkau, Tuhan?" Kata-Nya: "Akulah Yesus yang kauaniaya itu. Tetapi bangunlah dan pergilah ke dalam kota, di sana akan dikatakan kepadamu...dstnya.

Sejak pertobatan rasul Paulus, di kemudian ia begitu gigih memberitakan Injil. Dalam panggilan menginjili itu, ada banyak tantangan yang dihadapinya. Serangan yang dihadapinya berasal dari dalam dan luar. Serangan dari dalam adalah dari pihak orangorang percaya. Sebab mereka curiga dan takut akan pribadi Paulus. Ada yang beranggapan bahwa itu hanyalah suatu siasat atau kedok, yang mencoba membinasakan orang-orang Kristen. Fakta sebelumnya menunjukkan, bahwa Paulus berusaha membinasakan orang-orang Kristen. Mengapa kali ini justru berpihak kepada mereka? Sebaliknya, Paulus juga mendapatkan serangan dari luar, yang dulunya pro dengan Paulus. Mengapa di kemudian hari rasul Paulus berpihak pada orang Kristen? Dianggap dirinya berkhianat. Posisinya terlihat terjepit.

\footnotetext{
${ }^{16}$ Matthew Henry, Kisah Para Rasul, (Surabaya: Momentum, 2014), 354
} 
Walaupun demikian, ia tidak peduli akan hal itu. Prinsipnya, ia terus maju walaupun ada ancaman berat yang menghadang di depannya. Berhubungan dengan pemberitaan Injil, Paulus mempunya motto dan prinsip: "Celakalah aku, jika aku tidak memberitakan Injil” (1Kor. 9:16). Baginya, pemberitaan Injil itu adalah suatu keharusan yang tidak bisa ditawar-tawar. Paulus juga mengatakan bahwa orang yang memberitakan Injil akan hidup dari Injil itu (1Kor. 9:14). Artinya, ia benar-benar menggantungkan sepenuh hidupnya untuk Tuhan lewat penginjilan.

\section{Perjalanan Misi Rasul Paulus}

Sesudah mengalami pertobatan, Paulus begitu bersemangat dalam memberitakan Injil. Ia melakukan perjalanan penginjilan sampai tiga kali, yang merupakan bagian pelayanan misinya. Perjalanan penginjilan pertama diperkirakan tahun $47-48$ (Kis. 13:4 - 14:28). Pada perjalanan pertama ini, rasul Paulus didampingi teman sekerjanya, yaitu Barnabas dan Markus, "berangkat ke Seleukia, dan dari situ mereka berlayar ke Siprus" (Kis. 13:4). Siprus merupakan tempat asal Barnabas (Kis. 4:36). Mungkin gereja mempunyai beberapa kepentingan di sana karena orang Siprus (Kis. 11:20) termasuk di antara mereka yang pertama-tama mengabarkan Injil di Antiokhia. Di kota Pafos di pulau itu kita pertama kali mendengar Paulus membawa berita Kristen kepada seorang pejabat Roma, yakni pada waktu wawancaranya dengan Prokonsul Roma, Sergius Paulus (Kis. 13:6-12). Sejak saat itu dalam Kisah Para Rasul, ia selalu diberi nama Romawinya, Paulus, dan bukan lagi Ibraninya, Saulus.

Dari Siprus mereka berlayar menuju pesisir selatan Asia Kecil, dan kemudian melintasi wilayah pegunungan masuk ke Pisidia, ke kota lain yang disebut Antiokhia (Kis. 13:13-14). Mereka kemudian menuju ke arah timur, ke satu daerah yang disebut Likaonia, bagian dari Galatia, sebuah provinsi Roma (Kis. 13:51 - 14:7). Setelah pekerjaan misioner yang berhasil di beberapa kota, mereka kembali ke Antiokhia di Siria dengan mengikuti kurang lebih rute yang sama (Kis. 14:7-20), tetapi mereka tidak singgah lagi di Siprus (Kis. 14:21-28). ${ }^{17}$

Barnabas dan Saulus, disertai Yohanes Markus sebagai pembantu mereka, mengunjungi sinagoge-sinagoge dan memberitakan kabar baru di sana. Ketika berselisih dengan Elimas yang berusaha membelokkan iman gubernur, Paulus tampil ke depan. Karena ia tahu bahwa ilmu-ilmu setan yang dianut Elimas, Paulus mengecamnya di muka umum, dan mengutuknya. Gubernur terpesona melihat hukuman yang segera jatuh pada Elimas, dan percaya (Kis. 13:12). ${ }^{18}$

Setelah mereka melayani di sana mereka melanjutkan perjalanan ke Asia Kecil. Setibanya di Perge terjadi percekcokan antara mereka, dan akhirnya Markus meninggalkan mereka dan kembali ke Yerusalem. Paulus dan Barnabas melakukan perjalanan ke Antiokhia, Ikonium, Listra dan Derbe.

Adapun strategi misi mereka di sana adalah: terlebih dahulu mereka melayani orang-orang Yahudi di rumah-rumah ibadat mereka. Baru sesudah pemberitaan Injil itu

\footnotetext{
${ }^{17}$ John Drane, Memahami Perjanjian Baru, (Jakarta: BPK Gunung Mulia, 1996), 317

${ }^{18}$ Merril C. Tenney, Survei Perjanjian Baru, (Malang: Gandum Mas, 1993), 317
} 
ditolak, maka Paulus mengadakan pelayanan PI di antara orang-orang kafir. Di samping itu masih ada satu hal yang perlu diperhatikan, yaitu bahwa Paulus melayani kota-kota besar dan strategis lebih dahulu. Kemudian jemaat-jemaat yang baru itu menjadi pangkal untuk pelayanan yang lebih luas jangkauannya. Setelah pelayanan di Asia Kecil selesai, dia kembali ke Antiokhia. Di sana dia melaporkan tentang pekerjaan Tuhan dengan perantaraan mereka (Kis. 14:26-28). ${ }^{19}$ Fokus pelayanan Paulus dimulai dari orang-orang Yahudi, yang kemudian bangsa lain (Rm. 1:16). Artinya, bahwa pelayanan Paulus justru lebih banyak di luar orang-orang Yahudi.

Perjalanan penginjilan kedua diperkirakan tahun 49 - 52 (Kis. 15:36 - 18:22). Perjalanan misi ini dimulai dengan perselisihan antara Paulus dan Barnabas. Barnabas ingin lagi mengikut-sertakan kemenakannya yang bernama Yohanes Markus dalam pelayanan itu. Usul itu ditolak oleh rasul Paulus. Rupaya dia masih kecewa karena Yohanes Markus meninggalkan mereka dalam perjalanan misi pertama (Kis. 13:13). Akhirnya Barnabas membawa Yohanes Markus ke Siprus dan mengikut-sertakan dia dalam pelayanan di sana. Sedangkan Paulus bersama-sama dengan Silas berangkat ke Asia Kecil. Di bawah pimpinan Roh Kudus, Paulus dan kawan-kawan sekerjanya tiba di Troas. Dari sana mereka menyeberang ke Makedonia oleh karena suatu penglihatan (Kis. 16). Mereka mengunjungi Filipi, Tesalonika dan Berea. Di mana-mana mereka mendirikan jemaat-jemaat yang baru, walaupun masyarakat setempat cukup keras menentang mereka. Timotius dan Silas ditinggalkan di Berea dan Paulus sendiri meneruskan sampai ke Atena (Kis. 17:16-34). Tempat yang dilayani paling lama oleh Paulus adalah kota Korintus. Di sana dia melayani bersama-sama dengan kawan-kawan sekerjanya (Kis. 18:1-17). Pada zaman itu Korintus merupakan kota strategis untuk pelayanan, karena kota itu adalah ibukota daerah itu. Paulus menumpang di rumah Priskila dan Akwila. Suami dan istri ini sangat berguna untuk Paulus juga dalam pelayanan di tempat-tempat yang lain, antara lain di Efesus (Kis. 18:24-16) dan di Roma (Rom. 16:3-4). Rupa-rupanya mereka merupakan perintis jalan untuk Paulus di banyak tempat. ${ }^{20}$ Hal ini menunjukkan bahwa rasul Paulus menjadikan orang lain sebagai mitra kerja untuk memperlancar pelayanan misi yang dilakukannya.

Marxsen merinci dengan jelas akan perjalanan penginjilan kedua rasul Paulus ini dengan lengkap. Setelah persidangan para rasul yang dilaksanakan di Yerusalem, Paulus kembali ke Antiokhia (Kis. 15:30). Dari situ ia menempuh perjalanan penginjilan kedua (Kis. 15:36). Mula-mula ia mengunjungi gereja-gereja yang telah terbentuk di Siria dan Kilikia (Kis. 15:41). Kemudian melanjutkan ke Derbe dan Listra (Kis. 16:1). Rutenya membawanya ke Asia Kecil (Frigia dan Galatia), ke Troas (Kis. 16:8) dan terus ke Makedonia (Kis. 16:9 dyb.), dengan singgah di Samotrake, Neapolis dan Filipi (Kis. 16:11-12). Setelah dari pembebasannya dari penjara ia melalui Amfipolis dan Apolonia ke Tesalonika (Kis. 17:1); di sana sekali lagi ia mendapatkan perlawanan. Ia melanjutkan ke Berea (Kis. 17:10) dan di sana ia meninggalkan Silas dan Timotius (Kis. 17:14), lalu terus ke Atena (Kis. 17:18) dan memanggil kedua rekan yang telah

\footnotetext{
${ }^{19}$ Ola Tulluan, Introduksi Perjanjian Baru, (Batu: Departemen Literatur YPPII, n.d), 125

${ }^{20}$ Ola Tulluan, Introduksi Perjanjian Baru ..., 127
} 
ditinggalkannya untuk bergabung kembali. Ia melanjutkan ke Korintus (Kis. 18:1) dan tinggal di sana selama satu setengah tahun (Kis. 18:11) dan kemudian (setelah sebuah perkara yang melibatkan Prokonsul Galio) memulai perjalanan pulang dengan kapal lewat Efesus (Kis. 18:19) ke Kaisarea. Dari situ ia melanjutkan perjalanan ke Yerusalem, tetapi setelah singgah sejenak di sana berangkat lagi dan kembali ke Antiokhia (Kis. 18:22). ${ }^{21}$ Dapat diperhatikan di peta ini akan perjalanan pengkabaran Injil ke berbagai daerah yang menunjukkan bahwa Paulus begitu peduli dengan beberapa kota supaya mendengar berita Injil.

Perjalanan penginjilan ketiga diperkirakan tahun 52 - 56 (Kis. 18:23 - 21:17). Pada perjalanannya ini, Paulus mengunjungi Asia Kecil. Sasaran yang pertama adalah Efesus, yaitu ibukota Asia. Selama hampir tiga tahun kota Efesus itu merupakan pusat pelayanannya. Sebelum Paulus datang ke Efesus, Priskwila dan Akwila sudah melayani di sana. Antara lain Apolos dari Alexandria, seorang ahli Taurat, sudah dilayani. Dikatakan bahwa mereka dengan teliti menjelaskan kepadaya Jalan Allah (Kis. 18:26).

Pelayanan Paulus di sana berhasil, dan setelah dia diusir dari rumah ibadat orang Yahudi, dia setiap hari berbicara di ruang kuliah Tiranus (Kis. 19:9). Dikatakan bahwa pengaruh pelayanan Paulus sedemikian luasnya, sehingga semua penduduk Asia mendengar firman Tuhan, baik orang Yahudi maupun orang Yunani (Kis. 19:10). Akhirnya tukang-tukang perak yang menjadi kaya oleh karena membuat kuil-kuil dewi Artemis, menghasut masyarakat dan mengadakan huru-hara. Mereka menganggap pelayanan Paulus berbahaya untuk masa depan mereka sendiri (Kis. 19:21-40). ${ }^{22}$

Perjalanan penginjilan ketiga dimulai setelah kunjungan singkat ke Antiokhia (Kis. 18:23). Rutenya (menurut Kisah Para Rasul) melalui Galatia dan Frigia (Kis 18:23) ke Efesus (Kis. 18:24), dan di situ Paulus tinggal selama tiga tahun (bnd. Kis. 19:5, 10, 22, 20:31). Perlu dicatat bahwa di sini kita diberitahu tentang rencana untuk mengadakan perjalanan melalui Makedonia dan Akhaya ke Yerusalem dan kemudian ke Roma (Kis. 19:21). Paulus pergi ke Yunani lewat Makedonia dan di sana ia tinggal selama tiga bulan (Kis. 20:1-2). Perjalanan kembali membawanya melalui Makedonia (Kis. 20:3), Filipi dan Troas (Kis. 20:6) ke Asos (Kis. 20:14). Dari sana lewat laut melalui Metilene, Khioas dan Samos ke Miletus (Kis. 20:15); dan setelah persinggahan singkat ia melanjutkan perjalanan ke Tirus (Kis. 21:3), Ptolemais (Kis. 21:7) dan akhirnya ke Kaisaria (Kis. 21:8). Dari sana ia menyelesaikan perjalanannya ke Yerusalem (Kis. 21:15). ${ }^{23}$

Tentang kisah pelayanan Paulus begitu panjang lebar dikisahkan dalam Alkitab. Dari tulisan surat-suratnya juga dapat mengenal dan mengetahui akan sepak terjang yang dilakukan Paulus dalam pelayanan. Beberapa daerah sudah dijalaninya dan membuka pelayanan sehingga gereja bisa berdiri. Paulus pernah berkunjung ke Athena, ibukota Yunani. Di sana ia melihat orang-orang yang sedang mendirikan mezbah mempersembahkan kurban pada allahnya (dewanya). Di mezbah itu ada tulisan,

\footnotetext{
${ }^{21}$ Willi Marxsen, Pengantar Perjanjian Baru, (Jakarta: BPK Gunung Mulia, 1996), 7

${ }^{22}$ Ola Tulluan, Introduksi Perjanjian Baru..., 129

${ }^{23}$ Willi Marxsen, Pengantar Perjanjian Baru..., 8
} 
"Kepada allah yang tidak dikenal." Dengan melihat tulisan itulah Paulus mendapat kesempatan bagi orang-orang Yunani untuk memperkenalkan siapa Allah itu.

Demikian juga dalam suratnya ke jemaat di Galatia, menjelaskan bahwa Paulus pernah ke tanah Arab, yang kemudian melanjutkan perjalanan ke Damsyik (Gal. 1:17). Disebutkan bahwa Paulus mengadakan perjalanan ke Arab dan Damsyik selama tiga tahun (Gal. 1:17). Apa yang dilakukan Paulus di Arab? Alkitab tidak menjelaskan apa yang dilakukan Paulus di Arab. William Barclay memberi keterangan dalam buku tafsirannya "Surat Galatia dan Surat Efesus" mengatakan bahwa Paulus ke Arab untuk menyendiri dengan dua maksud tertentu. Pertama, untuk merenungkan peristiwa dahsyat yang telah menimpa dirinya. Kedua, sebelum ia berbicara kepada manusia, ia harus terlebih dahulu berbicara dengan Allah. ${ }^{24}$ Dalam bukunya yang lain, Barclay menulis, "Kalau ia lama tinggal di situ - kita tak tahu berapa lama ia menyendiri di situ tentunya ia dapat mencari nafkah dengan keahliannya. Pastilah orang-orang Arab yang berkelana itu senang untuk memberi makan dan minum kepadanya setelah ia memperbaiki tenda-tenda mereka." 25

Schnabel mengungkapkan akan maksud dan tujuan Paulus ke tanah Arab. Dia menyebut Arab adalah Arabia, yang dalam istilah Romawi dan Yahudi, Arabia di sini disebut juga Nabatea. Nabatea adalah wilayah di selatan provinsi Romawi, Siria. Wilayah ini mencakup Moab dan Edom dan membentang dari pegunungan Haran ke utara sampai ke wilayah timur dan barat Teluk Agaba. Kebanyakan penduduk Arabia adalah kaum Nabatean yang bahasanya merupakan pelopor Arab modern. Orang Yahudi memandang kaum Nabatean sebagai keturunan Ismael, anak Abraham, yaitu keturunan keluarga. Penerjemah Septuaginta mengaitkan kaum Nabatean dengan Nebayot, anak sulung dari 12 anak Ismael (band. Kej. 25:13; 28:9; 36:3; 1Taw. 1:29). Karena Idumea, "keturunan Esau", dipertobatkan (dengan paksa) pada Yudaisme oleh John Hyrcanus (135/34-104 s.M.), kaum Nabatean Arab muncul sebagai "saudara" terdekat orang Yahudi yang belum percaya kepada Allah. Kypros, ibu Herodes I, berasal dari keluarga kerajaan Nabatean. Salome, saudara perempuan Herodes, bermaksud menikah dengan Pangeran Nabatean Syllaios. ${ }^{26}$

Schnabel mengatakan bahwa Paulus tidak pergi ke Arabia untuk menindaklanjuti konsekuensi teologis dan praktis pertobatannya. Ia pergi ke Arabia untuk terlibat dalam pekerjaan misi. Buktinya adalah sebagai berikut:

1. Paulus menyatakan dalam Galatia 1:17 bahwa ia menaati panggilan Allah setelah perjumpaannya dengan Yesus Kristus yang telah bangkit - ia memberitakan Injil tanda berunding dengan para rasul di Yerusalem ketika ia pergi ke Arabia. "Tetapi waktu Ia, yang telah memilih aku sejak kandungan ibuku dan memanggil aku oleh kasih karunia-Nya, berkenan menyatakan Anak-Nya di dalam aku, supaya aku memberitakan Dia di antara bangsabangsa bukan Yahudi, maka sesaat pun aku tidak minta pertimbangan

\footnotetext{
${ }^{24}$ William Barclay, Galatia Efesus, (Jakarta: BPK Gunung Mulia, 1996), 24

${ }^{25}$ William Barclay, Duta Bagi Kristus, (Jakarta: BPK Gunung Mulia, 2001), 65

${ }^{26}$ Eckhard J. Schanabel, Rasul Paulus Sang Misionaris, (Yogyakarta: ANDI, 2010), 50
} 
kepada manusia; juga aku tidak pergi ke Yerusalem mendapatkan mereka yang telah menjadi rasul sebelum aku, tetapi aku berangkat ke tanah Arab dan dari situ kembali lagi ke Damsyik" (Gal. 1:15-17).

2. Paulus melaporkan dalam kaitannya dengan penderitaannya dan pekerjaannya sebagai rasul yang akan ditangkap oleh raja Aretas di Damsyik (2Kor. 11:32-33). Lukas mengacu pada insiden ini juga (Kis. 9:23-25). "Beberapa hari kemudian orang Yahudi merundingkan suatu rencana untuk membunuh Saulus. Tetapi maksud jahat itu diketahui oleh Saulus. Siang malam orang-orang Yahudi mengawal semua pintu gerbang kota, supaya dapat membunuh dia. Sungguhpun demikian pada suatu malam muridmuridnya mengambilnya dan menurunkannya dari atas tembok kota dalam sebuah keranjang." 27

Ada beberapa surat yang ditujukan kepada gereja-gereja yang pernah dilayaninya. Demikian juga suratnya ditulis kepada perseorang, seperti kepada Timotius, Titus, Filemon, yang menunjukkan betapa besarnya perhatian Paulus kepada anak didiknya. Bahkan, walaupun ia dalam penjara, masih menyempatkan diri menulis surat kepada jemaat anak rohaninya untuk menguatkan dan memotivasi mereka. Lihat saja surat kirimannya dari penjara kepada jemaat di Filipi. Penekanan surat Filipi adalah sukacita. Paulus berkata, "Bersukacitalah senantiasa." Dalam keadaan terjepit dan menunggu hukuman eksekusi, Paulus masih bisa bersukacita.

\section{Akhir Hidup Rasul Paulus}

Dalam bagian akhir kitab Kisah Para Rasul menjelaskan bahwa Paulus beserta rombongan yang menangkap dirinya sedang menuju ke Roma, tempat di mana nantinya Paulus dipenjara. Lukas juga ikut serta mendampingi Paulus dalam pelayaran ini. Pelayaran itu dipimpin seorang perwira yang bernama Yulius, dari pasukan Kaisar. Di perjalanan kapal yang ditumpanginya mengalami musibah. Tapi akhirnya selamat juga dan tiba di Roma.

Kalau membaca bagian akhir Kisah Para Rasul, sepertinya Paulus tidak dipenjara ketika sampai di Roma. Justru di Roma, Paulus bisa bertemu dengan orang-orang percaya di Forum Apius dan Tres Taberne (Kis. 28:15). Sepertinya Paulus hanya sebagai tahanan luar. "... Paulus diperbolehkan tinggal dalam rumah sendiri bersama-sama seorang prajurit yang mengawalnya" (Kis. 28:16). Dari tempat kediamannya inilah ia memanggil orang-orang terkemuka bangsa Yahudi, di mana ia nantinya akan menjelaskan duduk perkaranya mengapa ia ditahan dan dipenjara. Sebagian orang percaya dan terharu mendengar keterangan Paulus. Tapi sebagian lagi mengeraskan hatinya dan tidak percaya akan kesaksian Paulus. Karena itu, Paulus mengutip apa yang ditulis nabi Yesaya tentang keberadaan orang-orang yang hatinya keras itu. "Sebab hati bangsa ini telah, dan telinganya berat mendengar dan matanya melekat tertutup, supaya

\footnotetext{
${ }^{27}$ Eckhard J. Schanabel, Rasul Paulus Sang Misionaris..., 49
} 
jangan mereka melihat dengan matanya dan mendengar dengan telinganya dan mengerti dengan hatinya" (Kis. 28:27).

Paulus masih tinggal di rumah yang disewanya itu selama dua tahun penuh. Selanjutnya, tidak ada keterangan lagi akan apa yang terjadi di akhir hidup Paulus. Keterangan yang kita dapatkan adalah dari sumber lain. Pada masa akhir hidup Paulus, mungkin ia mengunjungi Efesus lagi dan bahkan sampai Spanyol. Yang jelas, akhirnya ia dihukum mati di Roma sekitar tahun 67. Menurut tradisi ia dipenggal di suatu tempat yang kini disebut Tre Fontane - 'Tiga Mata Air'. Sebab, begitu ditebas kepalanya terpentul tiga kali di tanah dan setiap kali muncullah mata air di tempat itu. Di atas makamnya sekarang berdiri 'Gereja S. Paulus di luar tembok'. Rencananya untuk mengunjungi Roma dan Spanyol menunjukkan bahwa ia ingin membandingkan kemegahan suatu negara dengan kemegahan iman.

Berdasarkan 2 Korintus 11:2-33, menjelaskan akan hal-hal yang dialami Paulus sesudah 25 tahun melayani Yesus Kristus, yaitu:

- Letih, dipenjara, dipukuli, mengalami bahaya maut

- Tiga kali disesah

- Satu kali dilempari batu

- Tiga kali kandas kapal

- Sehari semalam di dasar laut

- Banyak berjalan kaki

- Bahaya di daratan: sungai, rampok, saudara palsu, padang dan sebagainya

- Dikejar polisi Damsyik.

Berkat perjalanan rasul Paulus dalam mengabarkan Injil, sehingga banyak gereja yang berdiri. Ada juga gereja yang berdiri itu dirintis oleh murid yang pernah menjadi pengikut Paulus. Misalnya saja, Timotius dan Titus. Kedua tokoh mudah ini disebutkan dalam Alkitab, sebagai pemimpin muda yang menggembalakan jemaat Kristus.

\section{Pelayanan Misi Perkotaan Rasul Paulus}

Di sini dikemukakan akan pembelajaran yang sangat berharga dari berbagai pengalaman pelayanan penginjilan rasul Paulus, dimana ia dapat membangun gereja di Galatia, Makedonia, Akhaya dan Asia selama sepuluh tahun, oleh karena sebelum tahun 47 A.D. masih belum ada gereja di daerah-daerah tersebut. Hal menarik yang membuat rasul Paulus bersemangat dalam pengkabaran Injil adalah bahwa Injil itu kekuatan Allah (Rm. 1:16). Artinya, ia percaya bahwa ketika berita Injil disampaikan, maka Injil itu tidak kembali dengan sia-sia. Allah menyatakan kuasa-Nya pada orang yang mendengar Injil itu. Tugas orang percaya adalah hanya menyampaikan kabar baik (Injil) pada orang lain, khususnya pada orang-orang yang belum percaya. Karena Injil itu adalah kekuatan Allah sehingga rasul Paulus tidak malu memberitakannya. Dua hal yang dibahas pada bagian ini, yaitu: Faktor Pendorong Melakukan Misi. 


\section{Faktor Pendorong Melakukan Misi}

"Sebab aku mempunyai keyakinan yang kokoh dalam Injil, karena Injil adalah kekuatan Allah yang menyelamatkan setiap orang yang percaya, pertama-tama orang Yahudi, tetapi juga orang Yunani" (Rom. 1:16). Di sini, sebenarnya rasul Paulus berkata, "Sebab aku tidak malu terhadap Injil Kristus." Jadi, bukan bahwa ia "mempunyai keyakinan yang kokoh dalam Injil." Karena dalam bahasa Yunani tertulis:

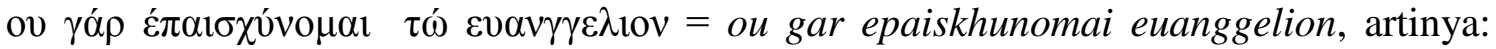
sebab aku tidak merasa malu karena Injil itu. Memang Paulus sadar bahwa orang percaya selalu tetap tergoda untuk merasa malu terhadap Injil Kristus. Sebab dari segi pandangan manusia, Injil Kristus tidak membanggakan. Raja kita dibunuh dengan sebuah salib, suatu kematian yang amat hina. Kita memberitakan kasih Allah, suatu berita yang mudah dicemoohkan. Masalah ini juga dihadapi dalam Markus 8:38; 1 Korintus 1:18; dan 2 Timotius 1:8. ${ }^{28}$ Apapun risiko dalam menjalankan misi yang dari Allah itu, dilaksanakan dengan sungguh-sungguh. Suatu pembelajaran bagi gereja di masa kini untuk terus gigih dalam memberitakan Injil.

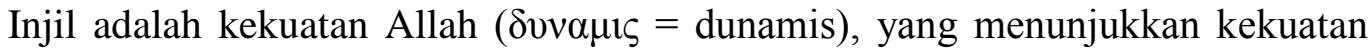
yang membawa keselamatan (1Kor. 1:18; 2:4; 1Tes. 1:5; 2:13; Ibr. 4:12). Paulus mengetahui hal ini berdasarkan banyak pengalaman yang telah ia alami. Ia mempunyai keyakinan yang kokoh bahwa Injil adalah kuasa Allah yang mendatangkan keselamatan untuk negeri dan bangsa Roma - bahkan untuk segala bangsa dan umat di atas muka bumi ini. Ia telah melihat kekuatan yang bekerja - kuasa dinamis dari Allah itu.

Bailey memaknai ungkapan ini dengan mengatakan bahwa ada suatu kuasa yang dikaitkan dengan setiap kebenaran. Setiap kebenaran memiliki kuasa untuk membuat orang terlepas dalam bidang tertentu itu; namun mereka harus percaya. Kuncinya adalah kepada setiap orang percaya, pertama-tama orang Yahudi, tetapi juga orang Yunani. ${ }^{29}$ Karena Injil yang berkuasa itulah sehingga Paulus memiliki roh keberanian untuk mewartakannya.

Hal kedua yang mendorong Paulus memberitakan firman Allah, yaitu bahwa pemberitaan tentang salib adalah kekuatan Allah (1Kor. 1:18). Hal yang berbanding terbalik dengan "Sebab pemberitaan tentang salib memang adalah kebodohan bagi mereka yang akan binasa." Supaya manusia tidak binasa, berita salib harus diwartakan. Itulah yang diungkapkan oleh Yohanes, di mana karena kasih Allah akan dunia ini sehingga Ia mengaruniakan Anak-Nya yang tunggal untuk keselamatan manusia (Yoh. 3:16). "Sebab kamu tahu, bahwa kamu telah ditebus dari cara hidupmu yang sia-sia yang kamu warisi dari nenek moyangmu itu bukan dengan barang yang fana, bukan pula dengan perak atau emas, melainkan dengan darah yang mahal, yaitu darah Kristus yang sama seperti darah anak domba yang tak bernoda dan tak bercacat" (1Pet. 1:18-19).

Sesuatu yang tidak logis bahwa Allah orang Kristen mati. Ini suatu kebodohan dan pembodohan; itulah ungkapan dan pernyataan bagi mereka yang akan binasa.

\footnotetext{
${ }^{28}$ Dave Hagelberg, Tafsiran Roma Dari Bahasa Yunani, (Bandung: Kalam Hidup, 1998), 25

${ }^{29}$ Brian J. Bailey, Lebih Dari Pemenang, (Jakarta: Voice of Hope, 2004), 17
} 
Padahal, justru dengan kematian-Nya itulah kuasa maut telah dikalahkan. "Maut telah ditelan dalam kemenangan" (1Kor. 15:54).

Bagi orang Yahudi, berita salib sangat sulit diterima. Yesus disalibkan dan mati dianggap suatu kelemahan, yang menunjukkan bahwa Allah tidak berdaya. Pada zaman ini, peristiwa penyaliban bukanlah kejadian yang luar biasa - melainkan sebuah kabar yang biasa dan tidak menarik. Memang tanpa makna rohani, peristiwa penyaliban hanyalah sekadar suatu kejadian di antara kejadian-kejadian yang sudah sering terjadi. Maka Paulus mendiskripsikan Injil sebagai batu sandungan bagi orang-orang Yahudi. Demikian juga, banyak orang yang tidak percaya tertutup matanya karena mereka tidak melihat mukjizat dalam peristiwa tersebut. Ini karena mereka mempunyai persepsi, pemikiran, dan harapan mereka sendiri tentang mukjizat. ${ }^{30}$ Ibrahim memberi alasan mengapa berita salib itu dianggap suatu kebodohan, yaitu:

1. Keadaan Yesus saat ini berada di atas muka bumi. Mereka menolak Yesus yang hidup di Nazaret, miskin, tidak memiliki rumah, tidak kaya dan tidak dihormati di antara sebangsa-Nya.

2. Mereka menolak Yesus karena kematian-Nya di salib, yang biasanya diperuntukkan bagi orang-orang berdosa.

3. Mereka tidak dapat melihat kemujaraban/keampuhan dalam kematian Yesus sebab mereka menganggap Ia tidak dapat menyelamatkan diri-Nya sendiri, bagaimana Ia menyelamatkan mereka.

4. Mereka buta terhadap keindahan karakter-Nya, ke-Allahan-Nya, penebusan-Nya, kuasa-Nya, dan lain-lain. ${ }^{31}$

Hal ketiga yang mendorong rasul Paulus dalam mengabarkan Injil adalah bahwa ia punya prinsip dan pengalaman, yaitu: "Bagiku hidup adalah Kristus" (Fil. 1:21). Paulus diperhadapkan dua pilihan: hidup dan mati. Hidup adalah Kristus dan mati adalah keuntungan.

Jika hidup adalah Kristus menunjukkan bahwa Kristus merupakan awal kehidupannya. Hal ini sesuai dengan pengalamannya ketika ia berjalan menuju Damaskus, seolah-olah memulai hidup yang baru sama sekali. Kristus adalah hidup yang sedang ia jalani. Tak satu hari pun dijalaninya tanpa kehadiran-Nya, dan dalam saat yang menakutkan Kristus hadir di sana untuk menghiburnya (Kis. 18:9-10).

Pemahaman akan pernyataannya ini ditegaskan dalam Galatia 2:20, "Aku hidup, tetapi bukan aku, melainkan Kristus yang hidup di dalam aku." Hidup yang dimaksud di sini ialah hiddup di dalam Kristus, ya Kristus sendiri. Paulus tidak takut menghadapi kenyataan yang ada, antara hidup dan mati. Kalau ia hidup, hal itu perlu bagi orangorang percaya di Filipi, tetapi untuk pergi dan tinggal bersama Kristus akan jauh lebih baik baginya. Paulus memutuskan bahwa Kristus mengingatkan ia tetap hidup, bukan hanya bagi kemajuan Injil (Fil. 1:12), tetapi juga agar mereka makin maju dan bersukacita dalam iman (Fil. 1:25). Ia ingin agar mereka menjadi perintis pertumbuhan

\footnotetext{
${ }^{30}$ Billy Kristanto, Ajarlah Kami Bertumbuh, (Surabaya: Momentum, 2006), 14-15

${ }^{31}$ David Ibrahim, Pelajaran Surat 1 Korintus, (Jakarta: Mimery Press, 1999), 15-16
} 
rohani di daerah-daerah yang baru. ${ }^{32}$ Memulai sesuatu pelayanan yang baru adalah hal yang mulia di mata Tuhan.

Abineno menambahkan, "Aku hidup, tetapi hidupku ditangkap dan dikuasai oleh Kristus, sehingga dengan jalan itu Ia hidup bagiku. Ia hidup menggantikan aku di dalam hidupku sendiri. ${ }^{33}$ Dengan ditangkapnya dirinya menjadi pelayan Kristus, Paulus terus bergerak memberitakan Injil ke berbagai daerah, dari kota ke kota. Misi perkotaan menjadi sesuatu hal yang penting baginya.

\section{Misi Perkotaan Paulus}

Dengan melihat perjalanan pelayanan misi yang dilakukan rasul Paulus menjadi suatu pembelajaran yang berharga bagi gereja masa kini. Perjalanan pelayanan misi yang dilakukan rasul Paulus dapat melahirkan banyak gereja di beberapa daerah. Pelayanan misi yang dilakukan itu menjangkau beberapa kota, di mana pelayanan yang dimulainya itu di kemudian hari didelegasikan kepada orang lain.

Pekerjaan misi yang dilakukan Yesus dan para rasul memberikan kepada kita penegasan bahwa pekerjaan misi dilakukan dengan strategi yang cukup jitu dan bersasaran. Dalam menjalankan misi pelayanan-Nya, Yesus berkeliling dari kota ke kota dan dari desa ke desa (Mat. 9:35a; Luk. 13:22). Dalam pelayanan-Nya, Tuhan Yesus melayani ke semua wilayah. Misalnya melayani di kota Kapernaum, suatu kota tempat kediaman pemungut cukai dan tempat sebuah pos militer Romawi (Mat. 4:13; 8:5). Melayani di Nazaret, melayani di padang gurun, dan melayani di pesisir-pesisir pantai dan sampai ke lembah-lembah. Tuhan Yesus juga melayani di Betania, dan daerah lainnya. Jadi, Tuhan Yesus dalam program pelayanan-Nya mencakup seluruh wilayah karena seluruh bumi adalah ladang misi penyelamatan-Nya. Tuhan Yesus berkeliling ke semua kota dan desa. Kata "berkeliling" menggambarkan aktivitas yang disadari dan terus-menerus.

Demikian juga pekerjaan misi yang dilakukan rasul Paulus; beliau sebagai seorang pelayan Injil yang sangat piawai dan berhasil dalam pencapaian yang melampaui dari apa yang dapat dilakukan orang-orang pada zamannya. Paulus dengan kebermegahan dari Tuhan mengatakan pada akhir masa hidupnya bahwa saatnya telah tiba baginya untuk mengakhiri pertandingan dan ia telah memelihara iman dan Injil. Artinya, Paulus menjalankan tugas misi sampai akhir hayatnya.

Dalam melaksanakan tugas misi dari kota ke kota, berbagai pendekatakan dipergunakan oleh rasul Paulus dalam menjangkau beberapa kota yang diinjilinya. Karena setiap daerah tentu beda dalam pendekatannya. Salah satu model pendekatan misi yang dilakukannya adalah kontekstualisasi, seperti yang dituliskannya kepada jemaat di Korintus, "Demikianlah bagi orang Yahudi aku menjadi seperti orang Yahudi, supaya aku memenangkan orang-orang Yahudi. Bagi orang-orang yang hidup di bawah hukum Taurat aku menjadi seperti orang yang hidup di bawah hukum Taurat, sekalipun

\footnotetext{
${ }^{32}$ Warren W. Wiersbe, Sukacita di Dalam Kristus, (Bandung: Kalam Hidup, 1994), 38

${ }^{33}$ J.L. Ch. Abineno, Surat Filipi, (Jakarta: BPK Gunung Mulia, 1996), 34
} 
aku sendiri tidak hidup di bawah hukum Taurat, supaya aku dapat memenangkan mereka yang hidup di bawah hukum Taurat" (1 Kor. 9:20).

Pendekatan yang dilakukan rasul Paulus sangat menarik dalam konteks di negara Indonesia yang majemuk dan pluralis. Yang perlu diingat bahwa berbicara tentang strategi bukanlah sesuatu yang menjadi pedoman mati karena bagaimana pun Roh Kudus adalah Roh yang dinamis. Tidak bisa kita melepaskan peran Roh Kudus ketika berbicara strategi misi. Sangat jelas terekam dalam Kisah Para Rasul bahwa Roh Kuduslah sebagai Causa Prima dalam pekerjaan misi dan pertumbuhan gereja. Daya gerak Roh Kudus merupakan dinamo yang mendorong dan memberi kuasa kepada Paulus untuk menjangkau bangsa-bangsa. ${ }^{34}$

\section{Model Misi Perkotaan Rasul Paulus Di Korintus}

Pada bagian ini membahas tiga hal yaitu: Kota Zaman Alkitab, Mengenal Kota Korintus, dan Model Misi Perkotaan Rasul Paulus di Korintus.

\section{Kota Zaman Alkitab}

Ketika Yesus melakukan pelayanan-Nya di Israel dan sekitarnya, Dia melakukan perjalanan dari desa ke desa dan dari kota ke kota. "Kemudian Yesus berjalan keliling dari kota ke kota dan dari desa ke desa sambil mengajar dan meneruskan perjalananNya ke Yerusalem" (Luk. 13:22).

Ada beberapa ayat Alkitab yang menjelaskan perjalanan pelayanan Yesus yang menelusuri pedesaan, terutama wilayah perkotaan, di antaranya: Matius 9:35-38; 11:1; $14: 13 ; 23: 34$; Luk. $7: 12 ; 8: 1 ; 8: 4 ; 9: 5 ; 10: 1$. Kristus pergi untuk mengajar dan memberitakan Injil di dalam kota-kota, tempat Ia pernah mengutus murid-murid-Nya untuk mendahuluinya mengadakan mukjizat-mukjizat (Mat. 10:1-8), dan dengan demikian membangkitkan harapan orang banyak dan untuk mempersiapkan jalan bagi kedatangan-Nya.

Hal ini menunjukkan bahwa Yesus begitu peduli dengan wilayah pedesaan dan perkotaan. Injil yang diberitakan Yesus dalam dunia ini berskala luas yakni menjangkau dunia ini bagi kerajaan-Nya. Dalam perjalanan pemberitaan Injil tempat yang menjadi sasaran adalah rumah-rumah ibadat di mana terdapat orang-orang beragama yang masih hidup di bawah kegelapan, dan juga di luar rumah ibadat. Banyak orang di luar gereja membutuhkan anugerah Allah.

Yesus memanggil ke-12 murid-Nya untuk diutus melakukan pelayanan misi ke berbagai tempat. Bahkan di lain kesempatan, Yesus memanggil 70 murid-Nya berduadua ke berbagai kota. Setelah Yesus menjelaskan akan kebutuhan untuk melaksanakan misi pengkabaran Injil bagi jiwa-jiwa yang tidak bergembala, Yesus meneguhkan panggilan mereka untuk menjadi utusan-utusan Injil. Injil yang harus diberitakan bukanlah berita politik maupun budaya, tetapi kabar baik. Ada berbagai kasus yang

34 Junifrius Gultom, Refleksi Atas Strategi Misi Rasul Paulus, (sumber : http://junifriusgultom.blogspot.co.id/2009/10/mencari-model-strategi-misi-i.html), diakses 31 Oktober 2017 
harus dihadapi murid-murid. Jiwa-jiwa yang terhilang umumnya hidup dalam cengkeraman kuasa kegelapan. Dalam hal ini pelayanan pengkabaran Injil tidak dapat dilakukan dengan kekuatan manusia. ${ }^{35}$

Karena itu, Tuhan Yesus memberi amanat yang penting dan urgen, yaitu supaya pergi memberitakan Injil (Mat. 28:19). Kata "pergi" dalam ayat ini berarti: menyeberangi batas-batas, baik secara sosiologis, rasial, kebudayaan, bahasa, atau geografis. Secara gramatika (bahasa Yunani) kata kerja utama dalam kalimat itu ialah "jadikanlah murid-murid". Tiga kata kerja lainnya: "pergi, baptiskan, ajarlah" menjelaskan bagaimana memuridkan. Jadi ini menjelaskan maksud "pergi".

Siapa yang harus pergi? Ke mana mereka harus pergi? Dan sebagainya. Siapa pun dan ke mana pun, tujuannya hanya satu, yaitu supaya tugas utama dapat diselesaikan: "Jadikanlah semua bangsa menjadi murid" Yesus. Ayat 20b merupakan janji yang indah. Janji ini sering dituntut di luar konteks yang benar. Lima hal yang perlu diperhatikan sehingga tercipta penginjilan yang seimbang, yaitu: kehadiran, pemberitaan Injil, dorongan, pendirian jemaat, dan pelipat-gandaan jemaat (1Kor. 1:17, 21, 23; 1Pet. 2:12; Kis. 2:47; 2Kor. 5:11; Rom. 15:23-24). Dan Allah memaksudkan umat Kristus untuk memiliki peranan penting dalam tujuan tersebut untuk mempercepat hari kedatanganNya.

George W. Peters mengemukakan tiga hal sebagai prinsip yang membuat pelayanan menjadi seimbang, yaitu: pengajaran, kesaksian dan penginjilan. ${ }^{36}$ Tiga pelayanan ini disebut semua dalam lima pasal pertama kitab Kisah Para Rasul. Kata "memberitakan Injil" ditemukan hanya sekali dalam bentuk kata kerja (5:42). Kata "saksi" dikaitkan hanya kepada rasul-rasul dalam bagian pertama Kisah Para Rasul.

Tolbert mengatakan bahwa memenangkan jiwa-jiwa bagi Kristus adalah pekerjaan terbesar di dunia, karena:

- Menawarkan kesempatan terakhir

- Menuntut tanggung jawab terbesar

- Menyampaikan tantangan terbesar

- Menghadapi perlawanan terbesar

- Menghasilkan keputusan terbesar

- Menghasilkan kepuasan terbesar

- Menerima dukungan terbesar

- Menerima penghargaan terbesar ${ }^{37}$

Tidak ada pencapaian sesuatu di dunia ini yang sebanding dengan sukacita melihat perubahan satu jiwa yang lepas dari maut menuju hidup.

Perlu diperhatikan dan diingat bahwa bukan setiap wilayah yang ramai penduduknya disebut sebagai kota (perkotaan). Ada beberapa daerah yang jumlah

\footnotetext{
${ }^{35}$ Makmur Halim, Model-model Penginjilan Yesus, (Malang: Gandum Mas, 2003), 53

${ }^{36}$ George W. Peters, Teologi Pertumbuhan Gereja, (Malang: Gandum Mas, 2002), 2

${ }^{37}$ John T. Tolbert, Practical Evangelism, (Malang: Gandum Mas, 2017), 17-19
} 
penduduknya besar, namun daerah itu masih tetap disebut sebagai desa. Tentu ada ketentuan suatu daerah sehingga disebut sebagai kota.

Mengapa misi perkotaan ini menjadi perhatian misi dari Yesus dan juga rasul Paulus? Kota merupakan pusat dari kehidupan manusia, di mana terdapat berbagai macam kehidupan yang majemuk. Berbagai macam persoalan ditemukan di sana. Belum lagi sifat yang egoistis, yang kurang peduli dengan sesama. Di sinilah peran gereja, yang dapat menjembatani orang-orang yang termarginalkan supaya mendekatkan diri kepada Allah. Gereja membawa kabar baik, yaitu Injil kepada mereka. Di setiap kesempatan, Paulus mengambil waktu untuk bersaksi memberitakan Injil.

Di daerah perkotaan, segala hal apa saja dengan gampang menyusup. Misalnya, sekularisme, modernisme, pluralisme, sinkretisme, yang intinya menekankan hal-hal keduniawian dan bersifat materialistis. Dampak dari semuanya ini sehingga terjadilah kemerosotan dalam gereja. Gereja terperangkap dengan sekularisme dimana nilai-nilai rohani dan Alkitab sudah ditinggalkan dan digantikan dengan nilai-nilai sekular/duniawi. Keanggotaan gereja hanya bersifat tradisi dan kebiasaan, dan kehidupan iman tidak berdampak sama sekali dalam kehidupan jemaat. Kawin cerai terjadi sama banyaknya di dalam gereja dengan yang di luar gereja. Belum lagi motivasi pendeta mulai merosot, khususnya gereja-gereja yang merasa sudah mapan (walaupun tidak semua atau sebagian kecil) dimana para pendeta kurang menyadari akan panggilan imannya. Jabatan kependetaan hanya dianggap sebagai profesi sama halnya dengan profesi lainnya. $^{38}$

Model dan gejala seperti ini sangat terlihat jelas di negara Eropa, yang membawa dampak pada penurunan akan kunjungan umat Kristus ke gereja. Yang datang ke gereja sedikit sekali. Tidak sebanding dengan kapasitas dan fasilitas gereja yang sangat besar. Akibatnya income gereja pun semakin minim, dan bahkan tidak mampu membiayai para pendeta yang menggembalakan gereja tersebut. Akhirnya, ada sebagian dari pendeta ini harus kerja sampingan untuk manambah income. Hal ini berlarut-larut tanpa ada penyelesaian, sehingga membuat ada gereja yang sampai tutup. Bahkan ada gereja yang dijual dan beralih fungsi. Yang lebih mencengangkan lagi, pernah di koran Jawa Pos memberitakan bahwa satu gereja di Australia beralih fungsi menjadi mesjid. Mengapa? Karena pengunjung (jemaat) semakin merosot yang hadir, yang membuat aset gereja terpaksa dijual. Herlianto melaporkan bahwa di negeri Belanda banyak gereja yang dijual untuk menjadi restoran, museum, toko, teater, bahkan menjadi perumahan. ${ }^{39}$

\section{Mengenal Kota Korintus}

Pelayanan dan kunjungan rasul Paulus ke kota Korintus dikisahkan dalam Kisah Para Rasul 18:1-7. Perjalanan ke kota ini dilakukan setelah kunjungannya ke Atena, Yunani (Kis. 18:1). Perjalanannya ke kota ini termasuk bagian dari perjalanan penginjilan kedua rasul Paulus, yang diperkirakan pada tahun 49 - 52. Paulus

\footnotetext{
${ }^{38}$ Herlianto, Gereja Modern Mau ke Mana? (Bandung: Yabina, 1995), 35.

${ }^{39}$ Herlianto, Gereja Modern Mau ke Mana?..., 36
} 
meninggalkan Atena setelah penginjilan yang ia lakukan dilecehkan penduduk (Kis. 17:16-34).

Rute kunjungan kedua dikisahkan dalam Kisah Para Rasul 15:36 - 18:22. Dalam perjalanan kedua ini sempat terjadi konflik perselisihan antara Paulus dengan Barnabas. Barnabas ingin lagi mengikut-sertakan kemenakannya yang bernama Yohanes Markus dalam perjalanan misi ini. Usul itu ditolak rasul Paulus. Alasannya, karena Markus pernah meninggalkan mereka dalam perjalanan misi pertama (Kis. 13:13), yang membuat Paulus kecewa. Di sinilah perpisahan pelayanan Paulus dan Barnabas. Paulus mengajak Silas dalam perjalanan misinya ini ke wilayah Asia Kecil. Sedangkan Barnabas mengajak Yohanes Markus ke Siprus. Namun demikian, pelayanan misi tetap berjalan dengan baik.

Di Korintus, Paulus bertemu pasangan suami istri, yaitu Akwila dan Priskila, yang berasal dari Pontus (nama Priskila merupakan bentuk akrab dari Priska). Suami istri ini juga baru datang dari Italia. Mereka terpaksa keluar dari Italia karena ada perintah dari kaisar Kladius, supaya semua orang Yahudi meninggalkan Roma (Kis. 18:2), yang diperkirakan tahun 49. Dalam buku Ensiklopedi Alkitab Masa Kini 1 menjelaskan bahwa pengusiran itu mengikuti terjadinya gangguan dalam masyarakat Yahudi Roma mengenai agama Kristen. ${ }^{40}$ Klaudius mengusir orang-orang Yahudi ke luar dari Roma, karena menimbulkan kerusuhan terus menerus, dengan Chrestus sebagai pemimpinnya. Suetonius mengidentifikasi sekte Yahudi Kristen muncul karena hasutan Chrestus, ejaan untuk Kristus dalam buku-bukunya. ${ }^{41}$ Maklumat akan pengusiran orang Yahudi ini diumumkan sekitar tahun 49-50.

Mengenai kaisar Kladius, dengan nama lengkap: Tiberius Claudius Caesar Augustus Germanicus (1 Agustus 10 SM - 13 Oktober $54 \mathrm{M}$ ) adalah anak dari pasangan suami istri: Drusus dan Antonia Minor (putri bungsu Marcus Antonius dengan Octavia). Claudius membuat Kekaisaran Romawi menjadi lebih luas dengan mengirim pasukan untuk menaklukkan Britinia (Inggris modern), dan dengan pengambil-alihan politik di berbagai tempat, yaitu: Thrace, Noricum, Pamphylia, Lycia dan Yudea (Israel modern). Dia juga membuat sistem pengadilan menjadi lebih adil, meskipun ia mudah dibujuk dan kadang-kadang tidak dapat menjadi seadil yang dia inginkan. Ia memberi lebih banyak hak kepada para budak dan wanita. Dia membangun pelabuhan besar di Ostia, memudahkan pengiriman gandum ke Roma dari Afrika dan Mesir melalui laut. Dan dia membangun 2 Aqueduct (saluran air) yang besar, yaitu: Aqua Claudia (pembangunannya sudah dimulai sejak zaman Caligula) dan Anio Novus. Ia juga memperbaiki yang lain, yaitu Aqua Virgo. ${ }^{42}$

Diduga, atas dasar-dasar yang tak meyakinkan, dia membuat tiga keputusan yang berbeda untuk menangani orang Kristen, yaitu:

(a) Ia mengusir orang Yahudi dari Roma karena membuat huru-hara atas hasutan Krestus (Suetonius, Claudius 25). Mungkin inilah kejadian yang disebut

${ }^{41}$ Sumber: https://id.wikipedia.org/wiki/Suetonius (diakses 6 Desember 2017)

${ }^{42}$ Sumber: https://id.wikipedia.orag/wiki/Claudius (diakses 6 Desember 2017) 
dalam Kisah Para Rasul 18:2. Krestus mungkin adalah nama orang, atau ejaan lain dari Kristus. Suetonius menerima yang pertama; lagi pula ia mengenal agama Kristen. Juga seandainya ia salah, sebutan itu tak perlu menunjuk kepada mesianisme Kristen. Baik kedatangan Paulus yang dengan selamat di Roma maupun suratnya yang ditujukan kepada orang Roma, tidak memberi kesan adanya pertentangan antara Yahudi dan orang Kristen di sana.

(b) Klaudius mencela para penghasut Yahudi yang memasuki Aleksandria dari Siria (H. I Bell, Jews and Christians in Egypt, 1924). Tapi pengetahuan Apolos dari Aleksandria yang tak sempurna mengenai agama Kristen, memberi kesan bahwa orang Yahudi itu bukanlah orang Kristen.

(c) Satu keputusan Kaisar (JRS, 22, 1932, hlm 184 dst), barangkali dari Klaudius, menghukum perampokan makam dan agaknya surat keputusan itu diterbitkan di Galilea. Apakah ini menunjuk kepada kebangkitan atau tidak, barangkali akan tetap suatu pokok yang dapat diperdebatkan.

Akwila dan Priskila ini adalah seorang Yahudi, yang tinggal di Korintus, yang berprofesi sebagai tukang kemah atau pembuat tenda (1 Kor. 18:3). Paulus pun ikut serta sebagai pembuat tenda, yang bekerja sama dengan keluarga ini. Pasangan ini bersedia menampung rasul Paulus untuk tinggal di rumahnya di Korintus. Dalam buku "Handbook to The Bible" tertulis bahwa mereka melakukan perjalanan ke Korintus, Efesus dan kembali ke Roma. Di mana pun pasangan yang ramah ini berada, mereka selalu menjadi pendukung jemaat-jemaat baru. ${ }^{43}$

Korintus adalah ibukota Akhaya, yang menjadi pusat perdagangan yang ramai dengan segala kemungkinannya. Kota Korintus merupakan kota Yunani kuno yang terletak di genting tanah yang bernama sama, yang berada di ujung barat Isthmus, di antara Yunani pusat dan Peloponesus, yang menguasai jalur perdagangan antara Yunani utara dan Peloponesus, dan melintasi Isthmus. Banyak barang diangkat lewat Isthmus ketimbang melingkari tanjung selatan Peloponesus yang banyak angin ributnya itu.

Ada dua pelabuhan, Lekheum, 2,5 km sebelah barat di teluk Korintus, yang dihubungkan dengan kota Korintus oleh tembok-tembok yang panjang, dan Kengkrea, $14 \mathrm{~km}$ sebelah timur di teluk Saron. Demikianlah kota Korintus menjadi pusat perdagangan yang berkembang, juga menjadi kota industri, khususnya industri keramik (barang tembikar). Kota itu didominasi oleh Akrokorintus $(566 \mathrm{~m}$ ), batu karang yang curam, dengan puncaknya yang datar, tempat akropolis, di mana pada zaman kuno terdapat satu kuil dari Afrodite, dewi asmara. Pelayanan dewi itu menimbulkan imoralitas kota yang menjadi pepatah, yang telah dicatat pada zaman Aristofanes. ${ }^{44}$

Karena letaknya yang strategis, Korintus menjadi saingan bagi pusat-pusat kota lainnya di Yunani, seperti Athena, Thebes, dan Sparta bahkan sejak lama penduduk Korintus saling bermusuhan dengan penduduk Athena. Pada awalnya, Yunani berada di bawah kekuasaan Makedonia. Orang-orang Yunani kehilangan kemerdekaannya pada

43 Kalam Hidup, 2002), 633

Handbook to The Bible - Pedoman Lengkap Pemahaman Alkitab, (Bandung:

44

,Ensiklopedi Alkitab Masa Kini 1, (Jakarta: YKBK, 1994), 582 
tahun 338 SM. Mereka dikuasai Philipus II dari Makedonia dan putranya, Iskandar Agung, menjadikan kota Korintus sebagai pusat pemerintahan. Usaha dan perjuangan orang-orang Yunani untuk memerdekakan diri dari jajahan Makedonia, dimanfaatkan oleh Kerajaan Italia untuk melakukan intervensi, pada akhirnya Korintus pun jatuh ke tangan Italia (Roma) pada tahun 146 SM.

Bangsa Roma dengan gencar ingin menguasai dunia. Saat mereka mencoba memusnahkan Yunani, Korintus menjadi yang terdepan melakukan perlawanan. Namun bangsa Yunani tidak dapat bertahan melawan bangsa Roma yang disiplin, dan pada tahun 146 SM, Lucius Mummius, jenderal Roma, merebut Korintus dan memorakporandakannya sebagai puing-puing.

Ternyata letak Korintus yang strategis itu tidak dibiarkan berlama-lama sebagai puing-puing. Pada tahun $46 \mathrm{SM}$, Julius Caesar mengirimkan sejumlah veteran dan orang-orang yang dimemerdekakan untuk membangun kota Korintus dan menjadikan sebagai wilayah jajahan kerajaan Italia. Kaisar Agustus menjadikan Korintus sebagai ibukota propinsi Akhaia dan tempat kedudukan prokonsul. Bahasa resmi penduduk Korintus ialah bahasa Latin, tetapi bahasa sehari-hari ialah bahasa Yunani (Gerika). ${ }^{45}$

Melihat wilayah Korintus yang strategis ini sehingga kota ini dijuluki sebagai "Pasar Negara Yunani". Ada catatan bahwa banyak barang-barang berharga didatangkan ke pelabuhannya, yaitu minyak balsem Arab, lontar Mesir, kurma Fenisia, gading Libia, permadani Babel, bulu kambing Kilikia, bulu domba Likaonia (Lycaonia), dan budakbudak Frigia. Kapal-kapal dari seluruh dunia berlabuh di dermaga Korintus, tempat kapal-kapal Yunani kuno yang termasyur itu mula-mula dibangun. ${ }^{46}$

William Barclay mencatat bahwa ketika Paulus hidup, penduduk kota Korintus beragam seperti berikut:

(i) Veteran-veteran Roma yang ditempatkan Julius Caesar di sana. Ketika seorang prajurit Roma sudah purnabakti, dia diberi status kewarganegaraan. Kemudian dia dikirim ke sejumlah kota yang baru didirikan dan diberi sebidang tanah sehingga dia bisa menjadi penghuni tetap di sana. Kolonikoloni Roma ini ditempatkan di seluruh dunia. Tulang punggung kolonikoloni tersebut biasanya adalah para veteran yang dengan setia mengabdi hingga mereka memperoleh imbalan kewarganegaraan tersebut.

(ii) Saat Korintus dibangun kembali, para pedagang kembali ke sana, sebab, Korintus masih unggul di bidang perdagangan.

(iii)Di antaranya ada banyak orang Yahudi. Pembangunan kembali kota menawarkan kepada mereka kesempatan untuk berdagang.

(iv) Ada beberapa orang Fenisia, Frigia dan orang-orang dari timur dengan adat istiadat mereka yang eksotis dan emosi yang meledak-ledak. Farrar berbicara tentang populasi para petualang Yunani dan kaum borjuis Romawi yang bastar dari heterogen, dengan pengaruh ketercemaran kaum Fenisia; massa

${ }^{45}$ J.S. Minandar, Kehidupan Sesuai Kehendak Tuhan, (Pare - Kediri: Dep. Lit. Dan M.M. MP-GPdI, 2002), 7

${ }^{46}$ Barclay, Duta Bagi Kristus, (Jakarta: BPK Gunung Mulia, 1999), 137-138 
orang-orang Yahudi, para mantan prajurit, para filsuf, pedagang-pedagang, para pelaut, narapidana, budak-budak, orang-orang belia, para pedagang keliling dan para pelaku semua tindak kejahatan. Farrar menyebut kekhasan Korintus sebagai koloni tanpa aristokrasi, tanpa tradisi-tradisi, dan tanpa warga kota yang berdomisili tetap (mapan). ${ }^{47}$

Sebelum masuk ke kota Korintus, terdapat Terusan Korintus. Terusan Korintus adalah terusan yang menghubungkan Teluk Korintus dengan Teluk Saronikos di Laut Aegea. Terusan ini menembus tanah genting Korintus dan memisahkan semenanjung Peloponesus dengan daratan Yunani. Terusan ini dibangun antara tahun 1881 hingga 1893. Panjangnya 6,4 kilometer dan lebarnya hanya 21,3 meter di dasarnya. Tebing daratan mengapit kedua sisi kanal mencapai ketinggian maksimum 63 meter. Selain dari yang kapal sederhana dan kapal pesiar ukuran menengah, Terusan Korintus tidak dapat dilewati bagi kebanyakan kapal modern.

Sebelum dibangun, kapal yang berlayar antara laut Aegea dan laut Adriatik harus mengelilingi Peloponnese yang artinya menempuh jarak yang lebih jauh sekitar 185 mil laut untuk perjalanan mereka. Orang pertama yang memutuskan untuk menggali Terusan Korintus adalah Periander, seorang tiran di Korintus (602 SM). Namun karena proyek raksasa ini di luar kemampuan teknis zaman itu, Periander akhirnya memerintahkan proyek besar lainnya yaitu diolkós atau jalan batu, di mana kapal-kapal itu dipindahkan pada platform beroda dari satu laut ke laut yang lain.

Dimitrios Poliorkitis, raja Makedonia (300 SM), adalah orang kedua yang mencoba, tapi insinyurnya bersikeras bahwa jika kedua lautan tersebut dihubungkan, Adriatik utara, yang dia anggap lebih tinggi, akan membanjiri Aegea selatan. Pada saat itu, ia juga berpikir bahwa Poseidon, dewa laut, menentang penggabungan antara laut Aegea dan Laut Adriatik. Ketakutan yang sama juga menghentikan Julius Caesar, Kaisar Hadrian dan Caligula.

Percobaan yang paling serius adalah di bawah perintah Kaisar Nero (tahun 67). A. Sizoo mengatakan bahwa sudah sejak dahulu kala orang membuat rencana untuk menggali terusan; rencana terakhir dibuat oleh kaisara Caligula, dan rencana itu kiranya diteruskan kaisar Nero. Para insinyur telah menentukan tempat yang paling baik untuk menggali terusan itu. Dalam gambar bagannya mereka telah membatasi dengan jelas jalannya terus itu, sehingga para insinyur modern pada kahir abad yang lalu tinggal meneruskan rencana dari zaman dahulu itu untuk menggali terusan yang dipakai sampai sekarang. Nero sendiri berkenan untuk membuka pekerjaan menggali dengan berbagaibagai upacara. ${ }^{48}$

Dia memiliki 6.000 budak untuk pekerjaan itu. Dia mulai bekerja sendiri, menggali dengan cangkul emas, sementara musik dimainkan. Namun, ia tewas sebelum pekerjaan dapat diselesaikan. Peristiwa ini dicatat Ludwig dari keterangan Morton:

Pada suatu hari yang sudah ditentukan, Kaisar Nero meninggalkan

Korintus dengan diiringi oleh pengawal-pengawalnya yang gagah dan

${ }^{47}$ William Barclay, Surat 1 \& 2 Korintus, (Jakarta: BPK Gunung Mulia, 2008),13-14

${ }^{48}$ A. Sizoo, Dari Dunia Perdjandjian Baru, (Jakarta: BPK Gunung Mulia, 1972), 167 
ketika ia sampai di sisi terusan itu, ia mengambil sebuah lyre (alat musik kuno berbentuk seperti harpa) dan menyanyikan sebuah lirik untuk menghormati Dewa Neptune dan Amphitrite. Kemudian ia memegang sebuah sekop emas. Sesuai dengan alunan musik, ia menancapkan sekop itu ke dalam tanah dan cidukan tanah serta rumput yang ada dalam sekop itu dimasukkan ke dalam sebuah keranjang yang digendong di punggungnya. Kemudian ia memberikan ceramah di hadapan para buruh, di antaranya ada enam ribu orang Yahudi yang baru ditangkap oleh Vespasianus dari desa-desa di sisi Danau Galilea, ketika pecah perang antara Yahudi melawan bangsa Romawi. Mengherankan bahwa pekerjaan menggali Terusan Korintus itu dimulai oleh tawanan-tawanan perang Yahudi yang nenek moyangnya pasti telah mendengarkan khotbah Tuhan Yesus di Laut Galilea. ${ }^{49}$

Di era modern, orang pertama yang berpikir serius untuk melaksanakan proyek ini adalah Capodistrias (1830), gubernur pertama dari Yunani setelah pembebasan dari Turki Utsmani. Tapi anggaran, diperkirakan 40 juta franc Perancis, terlalu banyak untuk negara Yunani. Akhirnya, pada tahun 1869, parlemen Yunani memberi mandat kepada Pemerintah untuk memberikan kesempatan kepada perusahaan swasta (Austrian General Etiene Tyrr) untuk mengerjakan proyek Terusan Korintus. ${ }^{50}$

Biarpun pada hakikatnya bercirikan kosmopolitan, kota Korintus cenderung menerima pengaruh Helenisme, dan pengaruh itu terasa di situ lebih daripada di kotakota lain. Kota itu pula menjadi tempat perjumpaan berbagai agama, baik asal Yunani maupun asal Timur. Kultus dewi Afrodite sangat berkembang di situ. Nama lain dari dewi Afrodite adalah dewi Venus. ${ }^{51}$

Bayu Probo menyebutkan bahwa seorang perempuan yang dicap perempuan Korintus, dianggap bermoral bejat. Di sisi lain, Korintus dikenal karena biaya hidup sangat tinggi sehingga penyair Yunani, Horatius, pernah berkata, "Tidak tiap orang mampu tinggal di Korintus. ${ }^{.52}$ Xavier Leon - Dufour menambahkan bahwa penduduk kota Korintus hidup dalam keadaan sosial yang sangat kontras (dua per tiganya adalah kaum budak), sedangkan hidup asusila di kota itu begitu umum. ${ }^{53}$ Sampai kota ini terkenal sebagai kota yang paling jahat di dunia.

Itulah sebabnya kota ini disebut Korintus, yang berasal dari kata korinthiazesthai, yang berarti hidup seperti orang Korintus. Kata ini menjadi kosa kata dalam bahasa Yunani. Kata ini berarti: hidup bermabuk-mabukan dan penyelewengan susila yang tak

\footnotetext{
${ }^{49}$ Charles Ludwig, Kota-kota Pada Zaman Perjanjian Baru, (Bandung: Kalam Hidup, n.d.), 42

${ }^{50}$ Sumber: http://www.kuakap.com/2016/05/asal-usul-terusan-atau-kanal-korintus.html?m=0 (diakses 6 Desember 2017)

51 "Kuil Afrodite terdapat di Akropolis (Korintus), di sebuah gunung batu dengan ketinggian dua ribu kaki, mendominasi seluruh genting tanah itu."

${ }^{52}$ Bayu Probo, Jejak-jejak Suci, (Jakarta: Inspirasi - BPK Gunung Mulia, 2010), 27

${ }^{53}$ Xavier Leon - Dufour, Ensiklopedi Perjanjian Baru, (Yogyakarta: Kanisius, 1997), 345
} 
terkendali. ${ }^{54}$ Nama kota Korintus juga berarti kemakmuran dan kemewahan, kemabukan dan tindak asusila serta perbuatan jahat (1 Kor. 6:9-10). Kata korinthiazesthai menggambarkan orang yang hidup berpesta pora dengan bermabuk-mabukan dan berbuat tak senonoh.

Henry mengatakan bahwa begitu terkenalnya percabulan di kota itu, sehingga perkataan perempuan Korintus diartikan dalam sebuah pepatah sebagai "pelacur." Kata korinthiazein, korinthiasesthai, yaitu mempermainkan orang Korintus, maksudnya pelacur atau bersundal. ${ }^{55}$ Pada umumnya kota-kota pelabuhan yang besar mempunyai perkampungannya sendiri tempat orang-orang bersundal dan melacur dan memuaskan nafsu dukananya. Dan Korintus pada zaman dahulu sudah terkenal di seluruh dunia sebagai tempat yang sudah mencapai nomor wahid di lapangan pelacuran. Sejak zaman kuno, di atas puncak bukit Akrokorinthos, di suatu tempat dari mana orang dapat terpesona oleh tamasya yang membentang luas di atas daratan dan lautan dan menunjukkan alam yang indah permai yang dijadikan oleh Tuhan Alkhalik, ada sebuah kuil kecil untuk menyembah dewi Aphrodite. ${ }^{56}$

Ada cerita bahwa, apabila ada tokoh dari Korintus dalam sandiwara zaman dahulu, mereka selalu harus diperankan pemabuk-pemabuk. Bahkan menganggap bahwa hidup ini hanya satu kali saja, maka harus dipuas-puasin. Dengan melihat kondisi yang seperti inilah sehingga Paulus menasihati jemaat di Korintus, "Janganlah kamu sesat: Pergaulan yang buruk merusakkan kebiasaan yang baik" (1Kor. 15:33).

Brill menyebutkan bahwa pengaruh agama terhadap penduduk Korintus sangat kuat, bahkan agamalah yang menyebabkan kejahatan mereka bertambah-tambah. Mereka menyembah Dewi Venus, sama seperti penduduk Efesus menyembah Dewi Diana, dan penduduk Atena menyembah Dewi Minerva. Dewi Venus adalah Dewi Cinta berdasarkan hawa nafsu. Dan peraturan di Korintus menetapkan bahwa di dalam kuil Dewi Venus itu harus ada seribu gadis cantik yang tetap tinggal di sana sebagai pelacur dan beribadah kepada Dewi Cinta itu. ${ }^{57}$ Demi kepentingan sang dewi, imam-imam wanita ini setiap malam turun ke jalan-jalan untuk menjalankan perdagangan mereka yang tak berakhlak itu. Maka lahirlah pepatah Yunani ini, "Tidak setiap pria mampu bepergian ke Korintus."

Sizoo menjelaskan lebih rinci akan pemandangan yang disaksikan rasul Paulus ketika mengunjungi kota Korintus ini. Rasul Paulus melihat banyak patung-patung dewa dan kuil-kuil kafir di Korintus. Pada perjalanannya dari Athena ke Korintus, ketika ia singgah di Kengkrea, ia sudah melihat patung besar dewa Poseidon, ialah dewa laut. Poseidon adalah dewa pelindung Isthmus dan untuk menghormati dia pada waktu-waktu tertentu diadakan perayaan Isthmus dengan bermacam-macam pertandingan, kira-kira seperti pertandingan Olympiade. Pertandingan itu menarik banyak sekali orang dari berjenis-jenis bangsa dan tingkatan dan selama hari-hari pertandingan itu kota Korintus

\footnotetext{
${ }^{54}$ William Barclay, Surat 1 \& 2 Korintus, (Jakarta: BPK Gunung Mulia, 2008), 11

${ }^{55}$ Matthew Henry, Surat Roma, 1 \& 2 Korintus, (Surabaya: Momentum, 2015), 495

56 A. Sizoo, Dari Dunia Perdjandjian Baru..., 170-171

${ }^{57}$ J. Wesley Brill, Tafsiran Sutar Korintus Pertama, (Bandung: Kalam Hidup, 1998), 11-12
} 
penuh sesak dengan orang asing. Tidak mengherankan, bahwa rasul Paulus dalam suratnya kepada orang-orang Korintus mengambil ibarat dari perlombaan dan pertandingan tinju (1Kor. 9:24-27). ${ }^{58}$ Selain itu, ada juga tempat-tempat suci lainnya, seperti: untuk memuja dewi Aphrodite (dewi asmara), Asklepios (dewa kesembuhan), dan Isis (dewi yang disembah bangsa Mesir).

Tetapi Korintus sendiri mempunyai lebih banyak patung dan kuil. Di tengahtengah alun-alun didirikan sebuah patung tembaga dewi Athena di atas alas kaki yang dihias dengan ukiran Muzen, yakni dewi-dewi kesenian dan ilmu pengetahuan. Dan di sisi alun-alun yang berukuran: panjang $=255 \mathrm{~m}$, dan lebar $=127 \mathrm{~m}$, dan salah satu alunalun yang paling besar di tanah Yunani didirikan patung-patung, misalnya: dewi Artemis (dewi Diana yang disembah oleh orang Efesus, terkenal dari Kis. 19), dewa Dionysus, dewa minuman anggur, dan ada lagi patung dewa Zeus dan Hermes (Jupiter dan Mercurius, terkenal dari Kis. 14:12). Kuil yang terpenting, yang dasar-dasar bangunannya didapatkan kembali, ialah kuil Asklepios. Kuil itu sudah sangat tua, ketika dirusakkan pada tahun $146 \mathrm{SM}$; sesudah tahun 44 SM, kuil ini dipugar seluruhnya. Bangunan yang sebenarnya menjadi kuil berukuran panjang $15,20 \mathrm{~m}$, dan lebar 8,26 m, tetapi di sekeliling lapangan kuil itu didirikan serambi-serambi berjajaran tiang dan di sebelah belakang serambi-serambi itu ada rumah-rumah tempat kediaman imam-imam. Dari sebuah kuil menurut pola Doria yang indah yang diperuntukkan bagi dewa Apollo, masih ada peninggalannya tujuh batang tiang atau pilar, yang hanya memberi gambaran yang samar-samar tentang keindahannya yang asli. Kota Korintus juga mempunyai tiga buah gedung sandiwara (yang paling besar dapat memuat 20.000 penonton), lima buah mata air dengan jaringan saluran airnya, lima tempat permandian, dua buah basilica, yakni rumah-rumah yang mempunyai ruangan yang besar dengan udara yang sejuk, baik sekali untuk mengadakan sidang pengadilan atau muktamar, sebuah gymnasium, yakni tempat untuk bersenam atau gimnastik, dan masih banyak lagi bangunan yang lainlainnya. Dengan melihat keterangan ini sangat jelas bahwa kota Korintus benar-benar indah dengan panorama yang menyenangkan.

Dengan adanya agama yang demikian, tidaklah heran kalau Korintus disebut sebagai kota kenajisan dan "Kota Main Korintus" yang berarti kota untuk berbuat zinah. Kota itu telah menjadi sangat najis dan penuh dosa di hadapan Tuhan, sehingga Korintus yang tadinya menjadi pusat olahraga dan kejahatan, akhirnya menjadi kota yang terlemah di seluruh Yunani.

Paulus tinggal di Korintus selama delapan belas bulan. Paulus tiba di Korintus diperkirakan pada musim gugur tahun 50. Barclay melukiskan perjalanan yang dilalui Paulus sehingga bisa sampai ke Korintus:

Setelah Paulus meninggalkan Atena, dia datang ke Korintus. Sebetulnya ia dapat berjalan melalui darat, tetapi perjalanan itu sangat berat, yaitu sejauh $64 \mathrm{~km}$ di jalan yang sulit dilalui, lewat kota-kota Eleusis dan Megara, dan rupa-rupanya Paulus terlalu lelah untuk melakukan perjalanan itu. Ia

\footnotetext{
${ }^{58}$ A. Sizoo, Dari Dunia Perdjanjian Baru, (Jakarta: BPK Gunung Mulia, 1972), 169
} 
memilih jalan laut, dan berlayar selama lima jam menyeberangi Teluk Saronik menuju pelabuhan Kenkrea. Paulus mempunyai mata seorang jenderal yang mampu melihat pusat strategis dan pangkalan terdepan yang vital. Bukti tentang kemampuan Paulus itu terdapat dalam keterangan seorang sarjana terkemuka yang mengatakan bahwa banyak dari kota-kota yang dikunjungi oleh Paulus dan di mana ia bekhotbah, sampai kini masih merupakan pelabuhan-pelabuhan yang besar dan pusat-pusat jalan yang ramai. 59

Paulus berhasil mendirikan jemaat di Korintus. Kemudian di pergi ke Efesus (1Kor. 18:18-19). Di Korintus ini Paulus bertemu kembali dengan Silas (Kis. 18:5, 11, 18). Paulus memisahkan diri dari persekutuan sinagoge karena mendapat tantangan dari orang-orang Yahudi ortodoks. Lalu mendirikan pos pekabaran Injil di dekat sinagoge itu, dengan bantuan seorang bekas pegawai sinagoge. Pos pekabaran Injil itu tadinya adalah rumah seorang penganut agama Yahudi asal Yunani (Kis. 18:5-8). Sebagaimana sering terjadi pertentangan seperti itu selalu dipakai oleh orang-orang Yahudi untuk melibatkan penguasa Romawi setempat. Tapi di Korintus itu penguasa Romawi tidak tertarik, karena pertentangan itu dianggap pertentangan intern agama Yahudi. Sikap penguasa Romawi setempat itu makin memberikan semangat kepada Paulus untuk meneruskan uaha pekabaran Injilnya (Kis. 18:12-17). ${ }^{60}$

Bruce menjelaskan akan percekcokan antara orang-orang Yahudi dengan Paulus, yang sebenarnya mau memojokkan Paulus di hadapan Yunius Galio, Gubernur Roma di Akhaya (ibukota Korintus), yang menuduh bahwa Paulus melakukan propaganda agama yang tidak sah menurut hukum. Bruce menjelaskan akan kepribadian Galio sebagai tokoh yang sangat menarik. Galio adalah saudara yang dikasihi dari Seneca, ahli filsafat Stoa dan guru pribadi kaisar Nero. Ia melihat apa yang ada di balik tuduhan yang sepintas lalu kelihatannya benar. Sekiranya Paulus memang telah melanggar hukum Roma, ia sudah mendengarkan permintaan mereka, katanya, tapi sebab soal itu tampaknya hanya mengenai kepercayaan dan tafsiran agama Yahudi, itu bukan urusannya. Ramsay menekankan pentingnya keputusan Galio ini sebagai contoh yang diikuti kemudian oleh gubernur-gubernur Roma lainnya dan sebagai tanda bagi Paulus bahwa pemerintah Roma dapat dipercaya untuk melindungi kebebasan pengkhotbahpengkhotbah Kristen, dan Paulus sendiri di kemudian hari naik banding kepada kaisar karena keyakinan ini. ${ }^{61}$ Apa yang terjadi sesudah Galio menolak permintaan Yahudi, pemukulan kepala rumah ibadat oleh rakyat jelata Yunani yang marah, menunjukkan bahwa ada perasaan anti Yahudi yang terpendam di kalangan rakyat pada waktu itu.

Paulus terdorong untuk menulis surat kepada jemaat itu karena ia mendapat berita tentang masalah-masalah yang timbul dalam jemaat itu. Surat itu hilang dan tidak terdapat dalam Alkitab kita (1 Kor. 5:9). Tentang isi keseluruhan dari surat yang hilang

\footnotetext{
${ }^{59}$ William Barclay, Duta Bagi Kristus, (Jakarta: BPK Gunung Mulia, 1999), 136

${ }^{60}$ Sri Wismoady Wahono, Di Sini Kutemukan, (Jakarta: BPK Gunung Mulia, 1994), 419

${ }^{61}$ F.F. Bruce, Kisah Para Rasul, dalam: Tafsiran Alkitab Masa Kini 3, (Jakarta: YKBK, 1990), 396
} 
ini tidak akan pernah diketahui, karena ia sudah hilang. Ada teori yang cemerlang yang mengatakan bahwa bagian-bagian dari "surat yang hilang" ini tersimpan dalam koleksi naskah di Korintus, dan bahwa 1 Korintus 6:12-20 dan 2 Korintus 6:14 - 7:1 adalah bagian surat itu, yang dirangkaikan dalam tubuh surat-surat Paulus yang lebih belakangan. Tenney menganggap bahwa teori ini hanya berdasarkan kesan subjektif belaka dan meskipun nampaknya ia sangat masuk di akal, tidak ada bukti eksternal yang dapat mendukungnya. ${ }^{62}$

Surat yang hilang itu mungkin tidak berhasil menyelesaikan masalah-masalah sebagaimana yang diharapkan Paulus, karena ia mendapat berita lagi dari keluarga Kloe bahwa ada masalah-masalah yang berat dalam jemaat itu (1 Kor. 1:11). Kemudian jemaat itu mengirim seorang utusan yang membawa surat kepada Paulus. Surat itu berisi pertanyaan-pertanyaan tentang pengelolaan dan doktrin jemaat (1 Kor. 7:1; 16:17-18). Untuk menjawab surat dan berita buruk yang didengarnya itu, Paulus menulis surat yang sekarang kita kenal sebagai 1 Korintus. Ia menulis surat itu dari Efesus kira-kira tahun $51 .{ }^{63}$ Paulus menulis surat ini untuk mengatasi semua persoalan.

Paulus mendengar kabar buruk mengenai jemaat di Korintus, yang mungkin dari Timotius. Ia segera ke Korintus. Kunjungan ini sangat menyakitkan setiap orang. Paulus harus bertindak tegas. Ia kembali ke Efesus lalu menulis "surat yang penuh keprihatinan" untuk mereka (2Kor. 2:4). Titus membawa surat itu ke Korintus. Paulus memutuskan untuk segera bertemu lagi dengan Titus. Ia ingin tahu segera keadaan jemaat Korintus. Paulus dan Titus bertemu. Titus mengabarkan bahwa jemaat Korintus menyambut surat yang penuh keprihatinan seperti yang diharapkan Paulus. ${ }^{64}$

Menurut Pfitzner, dalam perjalanan misinya yang ketiga, Paulus menulis surat yang kedua, yang kita miliki sebagai Surat 1 Korintus. Selain itu, Timotius diutus ke Makedonia untuk mengunjungi Korintus (1Kor. 4:17; 16:10). Paulus telah bereaksi dalam suratnya terhadap laporan-laporan mengenai jemaat itu dan terhadap pertanyaanpertanyaan yang ditujukan kepada jemaat itu kepadanya. Tak dapat diragukan bahwa Timotius bermaksud untuk mengukuhkan hubungan antara Paulus dan jemaat tersebut. ${ }^{65}$ Sedangkan surat 2 Korintus ditulis di Filipi (Kis. 20) sekitar tahun 50-53., saat ia mengalami kesusahan besar. ${ }^{66}$ Paulus menulis 2 Korintus penuh dengan sukacita. Ia mendorong mereka menepati janji mereka membantu jemaat Yerusalem (2Kor. 8:10$15)$.

Tidak beberapa lama berada di Korintus, datanglah Silas dari Makedonia (Kis. 18:5). Karena Paulus tidak punya kenalan di kota yang besar itu dan tidak ada seorang pun yang membiayai hidupnya, maka hal inilah yang menyebabkan ia bekerja sebagai tukang tenda bersama pasangan suami istri, Akwila dan Priskila.

\footnotetext{
${ }^{62}$ Merrill C. Tenney, Survei Perjanjian Baru, (Malang: Gandum Mas, 2001), 366

${ }^{63}$ Warren W. Wiersbe, Hikmat di Dalam Kristus, (Bandung: Kalam Hidup, n.d.), 7

${ }^{64}$ Simon Jenkins, Peta Alkitab, (Jakarta: YKBK, 1994), 116-117

${ }^{65}$ V.C. Pfitzner, Kekuatan Dalam Kelemahan, (Jakarta: BPK Gunung Mulia, 1999), 2-3

${ }^{66}$ David Ibrahim, Pelajaran Surat 2 Korintus, (Jakarta: Mimery Press, 2000), ix
} 
Setiap hari Sabat Paulus masuk ke dalam rumah ibadat orang-orang Yahudi dan memberitakan Injil kepada mereka. Tetapi, karena mereka tidak mau menerima Injil, maka Paulus mengebaskan debu dari pakaiannya, lalu meninggalkan mereka serta berpaling kepada bangsa-bangsa asing. Lalu Krispus, seorang kepala rumah ibadat, percaya kepada Tuhan Yesus dan bersedia dibaptiskan. Pada suatu malam Tuhan berfirman kepada Paulus di dalam suatu penglihatan, "Jangan takut! Teruslah memberitakan firman dan jangan diam! Sebab Aku menyertai engkau dan tidak ada seorangpun yang akan menjamah dan menganiaya engkau, sebab banyak umat-Ku di kota ini" (Kis. 18:9-10).

Tetapi, karena kemajuan Injil dan pekerjaan rasul Paulus, orang-orang Yahudi di Korintus telah mendakwa dia di hadapan Galio, Gubernur Akhaya. Sesudah Galio mengerti macam tuduhan mereka itu, ia menolak dakwaan tersebut dan mengusir mereka dari ruang pengadilan. Lalu mereka memukul Sostenes, kepala rumah ibadat orang Yahudi, yang telah melawan rasul Paulus (Kis. 18:17). Tidak lama sesudah itu Paulus berangkat dari Korintus bersama-sama dengan Akwila dan Priskila menuju Efesus. Sesudah berpamitan dengan sahabat-sahabatnya di Efesus, Paulus meneruskan perjalanannya ke Kaisarea dan ke Yerusalem. Di sana Paulus tidak tinggal lama karena kemudian ia kembali ke Efesus.

Pfitzner menyebutkan akan sikap dasar orang-orang Korintus, yang dianggap salah. Pertama, mereka adalah orang-orang yang penuh semangat yang membanggakan diri karena memiliki Roh. Mereka merasa bijaksana dan mempunyai pengetahuan khusus (1Kor. 1:20-29; 8:1-2); tetapi rasul Paulus memperingatkan mereka bahwa mereka tidak berhikmat secara alamiah di masa lalu, dan tanpa kebenaran Kristus mereka tidak berhikmat di masa kini (1Kor. 1:26-31). Mereka menyongbongkan kedewasaan mereka, menyiratkan bahwa mereka telah mencapai tujuan iman (1Kor. 2:6; 4:6); Paulus menyebut mereka tidak dewasa (1Kor. 3:1-2; 14:20; 4:9-13).

Kedua, sikap orang Korintus terhadap perkawinan dan seks. Di satu pihak, sebagian orang tidak melihat masalah dengan mempertahankan hubungan dengan pelacur, sementara yang lainnya mengecam perkawinan, dan mempertanyakan apakah hubungan seksual harus terus berlanjut di dalam perkawinan (1Kor. $6-7){ }^{67}$

Lim menambahkan bahwa jemaat di Korintus mempunyai pemahaman yang salah akan karunia-karunia Roh Kudus. Yang terjadi di sana sebagai kritik yang mengatakan bahwa bahasa roh di Korintus hanya semacam celoteh yang tidak karuan, dan datang dari latar belakang Korintus yang menyembah berhala itu. Ternyata Paulus tidak menyuruh mereka untuk berhenti. Sebaliknya, ia berharap semua bisa berbahasa roh. Ia berbahasa roh lebih banyak daripada mereka semua. ${ }^{68}$ Itulah sebabnya secara khusus, rasul Paulus menjelaskan akan karunia-karunia Roh Kudus.

Ibrahim menyebutkan akan maksud dan tujuan Paulus menulis Surat 1 Korintus, yaitu:

\footnotetext{
${ }^{67}$ V.C. Pfitzner, Kesatuan Dalam Kepelbagaian, (Jakarta: BPK Gunung Mulia, 2000), 5

${ }^{68}$ David Lim, Spiritual Gifts, (Malang: Gandum Mas, 2005), 35
} 
a. Menegur dan memperbaiki kesalahan-kesalahan yang ada dalam gereja berhubungan dengan mental, moral, kehidupan rohani dan sosial dari jemaat di Korintus.

b. Menentang kesombongan intelektual. Orang-orang Yunani di sana sombong dalam bahasa, kesusasteraan, perpustakaan, pengetahuan, dan logika mereka.

c. Menegur dan memperbaiki pelanggaran susila serta perpecahan yang terdapat dalam jemaat Korintus. Percabulan dan kemabukan adalah karakter dosa di Korintus (1Kor. 5:1-11; 6:15-18; 11:21).

d. Menjawab pertanyaan-pertanyaan jemaat Korintus mengenai berbagai masalah di dalam gereja (1Kor. $7: 1 ; 8: 1 ; 12: 1 ; 16: 1) .{ }^{69}$.

Sedangkan maksud dan tujuan penulisan Surat 2 Korintus adalah:

a. Untuk mempertahankan misi kerasulan dan kekuasaan Paulus terhadap pengabar Injil palsu, yang sedang menghancurkan pengaruhnya.

b. Memberikan pengarahan sehubungan dengan perhimpunan orang-orang suci di Yerusalem (2Kor. 9:1-5).

c. Menunjukkan perlunya penghiburan dalam kedisiplinan seperti yang dimaksudkan dalam 1 Korintus.

d. Menunjukkan bahwa kemuliaan Perjanjian Baru lebih besar daripada Perjanjian Lama. ${ }^{70}$

Dengan menulis surat 1 dan 2 Korintus ini, rasul Paulus mau mengokohkan mereka supaya semakin teguh imannya di tengah peradaban yang rusak.

\section{Model Misi Perkotaan Rasul Paulus di Korintus}

Pada bagian ini mencoba melihat akan model misi perkotaan rasul Paulus di Korintus, yaitu dengan ungkapan dalam 1 Korintus 9:20-22, yaitu: Menjadi Seperti. Kontekstualisasi Sebagai Perwujudan Menjadi Seperti.

\section{Menjadi Seperti}

"Demikianlah bagi orang Yahudi aku menjadi seperti orang Yahudi, supaya aku memenangkan orang-orang Yahudi. Bagi orang-orang yang hidup di bawah hukum Taurat aku menjadi seperti orang yang hidup di bawah hukum Taurat, sekalipun aku sendiri tidak hidup di bawah hukum Taurat, supaya aku dapat memenangkan mereka yang hidup di bawah hukum Taurat. Bagi orang-orang yang tidak hidup di bawah hukum Taurat aku menjadi seperti orang yang tidak hidup di bawah hukum Taurat, sekalipun aku tidak hidup di luar hukum Allah, karena aku hidup di bawah hukum Kristus, supaya aku dapat memenangkan mereka yang tidak hidup di bawah hukum Taurat. Bagi orang-orang yang lemah aku menjadi seperti orang yang lemah, supaya aku dapat menyelamatkan mereka yang lemah. Bagi semua orang aku telah menjadi segala-galanya, supaya aku sedapat mungkin memenangkan beberapa orang dari antara mereka" (1Kor. 9:20-22).

\footnotetext{
${ }^{69}$ David Ibrahim, Pelajaran Surat 1 Korintus, (Jakarta: Mimery Press, 1999), xi-xii.

${ }^{70}$ Ibid., ix
} 
Dalam kutipan ayat tersebut, kata yang mendapat penekanan adalah "menjadi seperti". Kata "menjadi seperti" dalam versi Alkitab dalam Bahasa Indonesia Masa Kini (BIMK) menyebutnya "berlaku seperti", dan dalam banyak bahasa perlu diperjelas lagi artinya menjadi seperti hidup dengan cara seperti, atau: bertingkah laku dengan cara. ${ }^{71}$

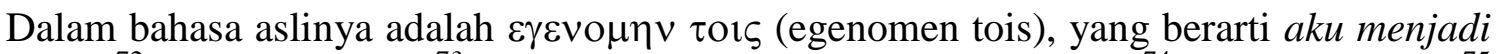
orang, ${ }^{72} i$ became to the ${ }^{73}$ (saya menjadi...), aku menjadi seperti, ${ }^{74}$ berlaku sebagai, ${ }^{75}$ saya hidup seperti. $^{76}$

Maksudnya di sini adalah bahwa rasul Paulus berusaha menjadi seperti orang lain yang didekatinya sesuai konteksnya. Paulus menyesuaikan dirinya dengan semua jenis orang. ${ }^{77}$ Semua jenis orang yang dimaksudkan di sini adalah: bagi orang Yahudi dan bagi orang-orang yang hidup di bawah hukum Taurat, bagi orang-orang yang tidak hidup di bawah hukum Taurat, bagi orang-orang yang lemah. Dan ini semua dilakukan karena Injil, supaya Paulus mendapat bagian di dalamnya, yaitu untuk kemuliaan Kristus (1 Kor. 9:23).

Warren W. Wiersbe memahami akan pendekatakan rasul Paulus ini dimana dalam kehidupan pribadinya, Paulus hidup sedemikian rupa hingga ia tidak mengganggu, baik orang-orang Yahudi maupun orang-orang bukan Yahudi. Ia tidak memperagakan kebebasannya di hadapan orang-orang Yahudi, ia juga tidak memaksakan hukum Taurat kepada orang-orang bukan Yahudi. ${ }^{78}$

Di sini ada penyesuaian diri. Itu pula yang dilakukan oleh Yesus, di mana Dia menjadi manusia seutuhnya. Dalam istilah teologisnya adalah berinkarnasi (Yoh. 1:14). Di sini tidak hanya dalam bentuk "seperti", tapi Allah yang adalah Firman (Yunani: Logos) telah "menjadi" manusia di dalam Pribadi Yesus.

Demikian juga ia berkata bahwa bahwa kepada yang lemah, yang sangat teliti dan berprasangka, ia sudah menjadi segala sesuatu supaya boleh dengan seboleh-bolehnya, ia dapat menyelamatkan beberapa orang. Hal itu tidak berarti bahwa ia merendahkan keyakinan kekristenannya. Atau menggadaikan iman yang dimilikinya.

\section{Menjadi Seperti Bentuk Pendekatan Kontekstualisasi}

Dengan melihat penjelasan tersebut, maka model misi yang dilakukan Paulus berdasarkan 1 Korintus 9:19-23 adalah bersifat pelayanan kontekstualisasi yang

${ }^{71}$ Paul Ellingworth \& Howard Hattom, Surat Paulus yang Pertama Kepada Jemaat di Korintus, (Jakarta: LAI, 2010), 242

${ }^{72}$ Hasan Susanto, Perjanjian Baru Interlinear Yunani Indonesia dan Konkordansi Perjanjian Baru, ( Jakarta: LAI, 2004), 916

73 Jay P. Green, Sr. (general editor), The Interlinear Bible Hebrew Greek English, (London: Trinitarian Bible Society, 1986), 889

${ }_{75}^{74}$ Kitab Suci Injil, (Jakarta: LAI, 2011), 793

75 __ Alkitab Bahasa Indonesia Seharis-hari, (Jakarta: LAI)

$76 \longrightarrow$ Alkitab Perjanjian Baru Dalam Terjemahan Sederhana Indonesia, (Yogyakarta \& Jakarta: ANDI \& Yayasan Albata, 2013), 458

${ }^{77}$ Matthew Henry, Surat Roma 1 \& 2 Korintus, (Surabaya: Momentum, 2015), 649

${ }^{78}$ Warren W. Wiersbe, Hikmat di Dalam Kristus, (Bandung: Kalam Hidup, n.d.), 128 
mencakup tiga hal, yaitu: tujuan, pendekatan dan tolok ukur. Ketiga hal ini akan diuraikan lebih terperinci.

\section{Tujuan}

Berdasarkan 1 Korintus 9:19 disebutkan bahwa tujuan dari pelayanan misi yang dilakukan oleh rasul Paulus adalah "supaya aku memenangkan sebanyak mungkin orang. Paulus berulang-ulang menyatakan alasannya: ia ingin memenangkan sebanyak mungkin orang, ia ingin mencari yang terhilang, dan menyelamatkan orang yang menuju kebinasaan. Dalam hal ini jelas sekali Paulus menyesuaikan diri demi keselamatan. Ini menunjukkan bahwa ayat-ayat ini menyatakan motivasi Paulus dalam penginjilan. Maka, salah satu wujud atau praktek memenangkan jiwa adalah lewat penginjilan. Sebab penginjilan itu adalah bagian dari peyanan misi.

Salah satu panggilan misi adalah penginjilan. Amanat dari misi itu adalah untuk pergi dan memuridkan orang-orang dari berbagai kelompok suku di dunia dalam Matius 28:19-20. Dalam mewujudkan tugas mulia ini, maka ada yang harus diutus. Tuhan Yesus pernah mengatakan suatu perumpamaan yang begitu menakutkan. Yesus berkata bahwa Ia akan mengutus kita sendiri seperti seekor domba di tengah-tengah serigala. Allah tidak pernah memberikan senjata yang cukup kuat bagi domba untuk melawan musuh-musuhnya. Domba hanya memiliki suara yang begitu lemah, yang enyatakan suatu kesedihan ketika menghadapi keadaan bahaya. Demikian juga ketika Allah Bapa mengutus Yesus ke dunia ini, Ia seperti domba di tengah-tengah serigala.

Yang menjadi dasar dari penginjilan adalah amanat agung Tuhan Yesus dalam Matius 28:19-20. Sebenarnya bukan hanya itu saja yang disebut amanat agung Tuhan Yesus. Dalam Injil Lukas dan kitab Kisah Para Rasul juga disebutkan akan amanat itu (Luk. 24:46-49; Kis. 1:8). Menjelang kenaikan-Nya ke surga, Yesus memberi perintah kepada Petrus, "Gembalakanlah domba-domba-Ku (Yoh. 21:15-17). Perintah menggembalakan domba-domba merupakan bagian dan buah dari penginjilan.

Secara aktual dan kenyataan di lapangan, pertumbuhan gereja itu disebabkan oleh beberapa faktor, yaitu: secara biologis, perpindahan, pertobatan (jiwa baru). Dalam konteks misi, maka pertumbuhan melalui pertobatan inilah yang disebut sebagai dampak dan akibat dari penginjilan. Salah satu dari tujuan penginjilan itu adalah pemuridan, yaitu supaya menjadi murid Kristus. Karena Yesus memberi perintah, "Jadikanlah semua bangsa menjadi murid-Ku..." (Mat. 28:19). Kata Yunani untuk "murid" adalah mathetes, dipergunakan 269 kali dalam kitab-kitab Injil dan Kisah Para Rasul. Kata itu berarti orang "yang diajar" atau "dilatih". Dalam Injil Yohanes, Yesus mendefinisikan kata murid dalam tiga cara:

a. Seorang murid adalah seorang Kristen yang tanpa putus-putusnya terlibat dalam firman Allah (Yoh. 8:31).

b. Seorang murid ialah orang yang menyerahkan nyawanya untuk orang lain (Yoh. 13:34-35). 
c. Seorang murid ialah orang yang setiap hari tetap bersekutu dengan Kristus sehingga menghasilkan buah (Yoh. 15:4-5). ${ }^{79}$

Dalam mendengar suara Roh Kudus, seseorang membutuhkan kepekaan yang khusus, yang Tuhan karuniakan kepada seseorang. Hal itu dapat terwujud jika seseorang memiliki hubungan yang baik dengan Allah, yaitu melalui doa. Henokh hidup bergaul dengan Allah, sehingga ia mengalami pengangkatan ke surga sebelum ia mengalami kematian jasmani (Kej. 5:23). Demikian juga nabi Nuh bergaul dengan Allah (Kej. 6:9), sehingga Allah membimbingnya untuk membuat sebuah bahtera. Karena ia dengardengaran, sehingga ia dan seluruh keluarganya diselamatkan dari persitiwa air bah. Dengan kepekaan yang sama, Paulus dan Silas juga mendapatkan suara yang mencegah mereka untuk memberitakan Injil ke Asia. Ada sesuatu maksud Tuhan yang terbaik, sehingga mereka diingatkan!

Yang jadi persoalan adalah bagaimana seseorang dapat membedakan antara suara hati nurani, suara keinginan dirinya sendiri, dan suara Roh Kudus. Hati nurani manusia menjadi tolok ukur dalam mempertimbangkan dan mengambil suatu keputusan. Dan di dalam hati nurani manusia itu pula Roh Allah (Roh Kudus) tinggal diam (1Kor. 3:16). Stephen Tong mengatakan bahwa hati nurani adalah daya dasar yang sudah Tuhan tanamkan di dalam diri manusia, yang langsung berasal dari Tuhan Allah sendiri. Istilah hati nurani, dalam bahasa Arab disebut: nur, yang artinya cahaya atau pencerahan. Hati nurani berarti hati yang bercahaya. Ketika hati kita bercaya, kita dapat melihat. ${ }^{80}$

Stephen Tong menjelaskan lebih rinci tentang hati nurani. Istilah yang dipakai dalam Alkitab (PB) adalah suneidesis, yang sama dengan istilah bahasa Latin: conscientia. Istilah ini terdiri dari gabungan dua kata: sun + desis atau: con + scientia. Istilah ini kemudian di dalam bahasa Inggris menjadi conscience, yaitu con + science. Istilah Inggris science berarti pengetahuan. Istilah ini menjadi istilah yang tidak asing, bahkan menjadi istilah penting bagi ilmuwan abad XX. Istilah science sebenarnya berasal dari kata scio. Kata scio, cogito dan credo merupakan kata-kata penting, dan dianggap sebagai tiga tahapan utama dalam suatu kebudayaan. Scio adalah apa yang kita tahu, kemudian cogito adalah apa yang kita pikirkan, dan credo adalah apa yang kita percaya. Ketika Allah menciptakan alam semesta ini, Allah telah menyimpan rahasia ciptaan itu di dalam alam semesta, maka manusia menggalinya, mencari dan menemukannya. Ketika menemukan itu, maka manusia mengatakan scio (aku tahu). ${ }^{81} \mathrm{Di}$ sini menekankan bahwa dalam melakukan tugas misi itu dilandasi dengan pengurapan kuasa Roh Kudus, yang dibuktikan dengan memiliki hati nurani yang tulus dan murni.

Namun hati manusia ini sudah tercemar oleh dosa. Karena itu, butuh pengampunan dan pengudusan dari Allah Roh Kudus, yang menyucikan hati manusia sehingga bisa dengan peka mendengar suara Roh Kudus. Stephen Tong menulis, "Roh Kudus bekerja di dalam diri kita terus-menerus, sampai akhirnya kita sadar akan standar

\footnotetext{
${ }^{79}$ Waylon B. Moore, Penggandaan Murid-murid, (Malang: Gandum Mas, 1981), 19-21

${ }^{80}$ Stephen Tong, Roh Kudus Suara Hati Nurani dan Setan, (Jakarta: Lembaga Reformed Injili Indonesia, 1997), 51-52

${ }^{81}$ Stephen Tong, Roh Kudus Suara Hati Nurani dan Setan..., 54-55
} 
Tuhan, dan kita menangisi akan dosa-dosa kita. Itulah akibat dari hidup baru, dimana Roh Kudus bekerja. Kalau Roh Kudus tidak menggerakkan kita, tidak mungkin kita bertobat." ${ }^{, 82}$ Karena itu, ada pertobatan total pada diri manusia, sehingga hati nuraninya semakin dimurnikan dengan standar dari Allah.

Dalam setiap pelayanan misi tidak bisa lepas dari pengurapan dan kuasa Roh Kudus. Tanpa Roh Kudus, maka segala upaya apapun yang dilakukan manusia akan siasia. Pertumbuhan gereja secara kuantitas dan kualitas tidak terlepas dari peran kuasa Roh Kudus. Ketika gereja mula-mula mengalami jamahan dan baptisan Roh Kudus, gereja

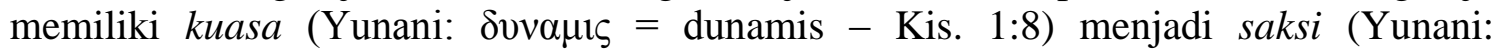
$\mu \alpha \rho \tau v \rho \imath \alpha=$ marturia). Tidak heran, ketika pertama kali rasul Petrus melakukan pengkabaran Injil, ada 3000 jiwa yang percaya dan menerima Tuhan Yesus serta menerima baptisan air (Kis. 2:41). Di lain kesempatan, jiwa-jiwa juga bertambah sampai 5000 jiwa, yang terdiri dari laki-laki (Kis. 4:4). Pertumbuhan secara kualitas terlihat dengan banyaknya jiwa-jiwa yang bertobat, seperti orang-orang yang pernah melakukan kegiatan sihir; di mana kelompok ini mengumpulkan kitab-kitabnya lalu membakarnya di depan semua orang. Padahal secara materi, nilai kitab ini sangat mahal, yang mencapai lima puluh ribu perak (Kis. 19:19). Belum lagi dalam bidang pelayanan (diakonia), di mana kelompok gereja mula-mula ini mengumpulkan harta bendanya untuk dibagi-bagikan kepada orang-orang yang membutuhkan (Kis. 4:32-37). Sesudah mereka dipenuhi Roh Kudus, ada kegerakan yang luar biasa untuk memberitakan Injil. Ada 120 orang yang berkumpul di loteng Yerusalem, yang menerima baptisan dan kuasa Roh Kudus. Stephen Tong menjelaskan ciri-ciri orang yang dipenuhi Roh Kudus, yaitu: taat pada Roh, hidup kudus, menjunjung tinggi firman, memberitakan Injil, berani menjalankan kehendak Allah, menghasilkan buah Roh. ${ }^{83}$ Salah satu ciri khas dipenuhi Roh Kudus yang disebutkan itu adalah memberitakan Injil. Inilah yang terjadi pada masa gereja mula-mula. Kiranya kegerakan ini juga terjadi pada masa gereja sekarang ini.

Ketika Paulus mengunjungi Korintus pada sekitar tahun 50 atau 51, ia sama sekali tidak tahu bahwa Allah akan memakainya untuk menghasilkan suatu jemaat yang besar dan berpengaruh di kota yang modern ini. la juga tidak tahu bahwa kota ini akan menyaksikan lahirnya kesusasteraan Kristen. Dari pandangan manusia hal ini sama sekali tidak mungkin. Meskipun Korintus terkenal sebagai pusat wewenang pemerintahan dan kota perdagangan utama di Yunani, dalam benak banyak orang, kota itu merupakan simbol pengumbaran hawa nafsu dan kemewahan tanpa batas, sedemikian merajalelanya sampai ungkapan "berkorintus" digunakan untuk "mempraktekkan perbuatan amoral". Sensualitas ini merupakan produk ibadat orang Korintus, khususnya ibadat kepada dewi Aphrodite (padanan dewi Venus dari Roma, dewi Astarte dari Fenisia dan Kanaan, serta dewi Istar dari Babilonia), yang dikenal sebagai dewi percintaan dan hawa nafsu.

${ }^{82}$ Stephen Tong, Dinamika Hidup Dalam Pimpinan Roh Kudus, (Jakarta: Lembaga Reformed Injili Indonesia, 1995), 29

${ }^{83}$ Stephen Tong, Roh Kudus, Doa dan Kebangunan, (Jakarta: Lembaga Reformed Injili Indonesia, 1997), 109-110 
Sebuah kuil yang dibaktikan untuk penyembahan kepadanya berdiri di puncak Akrokorintus, bukit terjal dan berbatu-batu yang menjulang setinggi 513 meter di atas agora. Seribu wanita bekerja sebagai tuna susila dari kuil itu serta merupakan bagian yang tidak dapat dipisahkan dari acara-acara kebaktian. Kota Korintus dikenal oleh dunia di sekitar Laut Tengah karena kebobrokan susilanya. Istilah Korintus melambangkan kehidupan yang diliputi oleh kemabukan dan percabulan. ${ }^{84}$

Sungguh beralasan apabila Paulus memberikan nasihat dan peringatan keras kepada orang-orang Kristen di Korintus berkenaan dengan perilaku moral (1Kor. 6:97:11; 2Kor. 12:21). Tentu saja, Korintus memiliki kuil-kuil untuk banyak dewa dan dewi lain. Di kuil Asklepios, sang dewa penyembuhan, para arkeolog telah menemukan patung-patung terakota dengan warna dan bentuk menyerupai bagian-bagian tubuh manusia. Patung-patung ini ditinggalkan di kuil itu sebagai persembahan dari para penyembahnya, masing-masing mewakili anggota tubuhnya yang sedang sakit (tangan, kaki, mata, dan sebagainya).

Selain orang Yunani, ada cukup banyak orang Italia keturunan para penjajah sebelumnya. Banyak murid asal Korintus yang mempunyai nama Latin, seperti Yustus, Tertius, Kuartus, Gayus, Krispus, Fortunatus, dan Akhaikus (Kis. 18:7; Rom. 16:22, 23; 1Kor. 1:14; 16:17). Sejumlah besar orang Yahudi telah bermukim di sana dan mendirikan sebuah sinagoga, yang didatangi oleh beberapa pengikut berkebangsaan Yunani (Kis. 18:4). Keberadaan orang Yahudi di Korintus ditunjukkan oleh inskripsi Yunani pada ambang pintu marmer yang ditemukan di dekat gerbang menuju Lekheum. Inskripsi itu, yang berbunyi "Sunagoge Hebraion" berarti "Sinagoga Orang Ibrani". Para musafir dan pedagang senantiasa datang, demikian pula orang-orang yang mencari kesenangan di kota hiburan dan atletik ini. Tidak diragukan, hal ini turut menghasilkan sikap yang lebih toleran daripada sikap yang dijumpai sang rasul di kota-kota lain yang dikunjunginya, termasuk Athena, pusat kebudayaan Yunani. Paulus menerima suatu penglihatan yang meyakinkan dia bahwa di Korintus ada banyak orang yang berkecenderungan adil-benar, maka ia tinggal selama satu setengah tahun di tempat yang strategis ini, yang merupakan pertemuan antara Timur dan Barat (Kis. 18:9-11). Pada waktu itulah, kemungkinan besar ia menulis dua pucuk surat kepada jemaat di Tesalonika. ${ }^{85}$

Ada upaya gigih yang dilakukan Paulus ketika di Korintus, yaitu memberitakan firman dan memberi kesaksian kepada orang-orang Yahudi bahwa Yesus adalah Mesias (Kis. 18:5). Namun ada saja orang-orang yang tidak senang dengan hal-hal yang dikerjakan Paulus. Di sinilah peran Roh Kudus dalam pelayanan misi Paulus, yaitu meneguhkan dan menguatkan dirinya. Dan Tuhan kirimkan juga orang-orang yang dapat menguatkan pelayanan Paulus, yaitu Titius Yustus.

Hasil pelayanan rasul Paulus pun terlihat nyata, di mana Krispus, kepala rumah ibadat menjadi percaya kepada Tuhan bersama-sama dengan seisi rumahnya. Dan

${ }^{84}$ Millard J. Berquist, Penjelidikan Surat Korintus Jang Pertama, (Bandung: Penerbitan Geredjageredja Baptis), 5

${ }^{85}$ Sumber: http://www.sarapanpagi.org/korintus-vt1666.html (diakses 4 Nopember 2017) 
banyak dari orang-orang Korintus yang mendengarkan pemberitaan Paulus, menjadi percaya dan memberi diri mereka dibaptis. Ciri khas keberhasilan pelayanan Paulus adalah membawa jiwa-jiwa datang kepada Yesus, yang ditindak-lanjuti dengan menerima baptisan air.

Pada suatu malam berfirmanlah Tuhan kepada Paulus di dalam suatu penglihatan: "Jangan takut! Teruslah memberitakan firman dan jangan diam" (Kis. 18:9). Bagian ini mengungkapkan perasaan batin sang rasul yang manusiawi. Rupanya pertentangan dan kebencian terhadap Paulus dan Injil makin bertambah sehingga Paulus mulai takut dan ragu-ragu apakah harus meninggalkan Korintus atau berdiam diri sebentar (1Kor. 2:3). Kadang-kadang perasaan yang sama akan timbul dalam hati umat Allah yang setia, seperti Elia (1Raj. 19:4) dan Yeremia (15:15). Kata "Jangan takut" (Yunani: $\mu \eta$ поßov) adalah kosa kata sekarang, yang berarti bukan melarang takut sesaat karena suatu kejadian yang terjadi, tetapi hidup terus-menerus tanpa ketakutan. ${ }^{86}$

Wiersbe mengatakan bahwa ucapan "Jangan takut!" yang lemah lembut itu dapat meneduhkan badai di dalam hati, sesulit apapun keadaan di sekeliling kita. ${ }^{87}$ Di sini Paulus tidak boleh tutup mulut karena takut, tetapi ia harus berbicara karena iman. Dengan sapaan Allah "Jangan takut!" menguatkan dan memberi keberanian bagi Paulus. Atas dirinya tidak akan terjadi apa-apa, sebab Kristus hendak mempergunakannya untuk memungut panen. Terkadang karena takut, dengan mudahnya orang tutup mulut. Berbicara dan bersaksi di dalam dunia dimana semuanya rupanya menentang Allah dan ibadah kepada-Nya menimbulkan permusuhan dan kebencian. ${ }^{88}$

Berg mengatakan bahwa Paulus harus terus memberitakan firman dan jangan mau dibungkam. Ada dua alasan untuk hal ini, yaitu: 1) Tuhan mengatakan, "Aku menyertai engkau" dan tidak ada seorang pun yang akan berani menyentuh engkau. Paulus mendengar hal itu dari sang Kurios sendiri yang mengalahkan maut dan menjadi raja dunia. 2) Tuhan telah menyertakan banyak warga Korintus dalam rencana keselamatan-Nya, "banyak umat-Ku di kota ini" (bnd. Yoh. 10:16). Mereka harus ditarik oleh pemberitaan Paulus. Tuhan berkenan menyingkapkan ujung tirai sejenak, sehingga Paulus dapat melihat tuaian yang berlimpah di Korintus. ${ }^{89}$

Dengan berbagai pelayanan misi yang dilakukan Paulus sehingga banyak gereja berdiri. Alkitab mencatat dengan jelas akan perjalanan misi yang dilakukan Paulus, yang sampai tiga kali perjalanan, di mana ia singgah ke beberapa kota. Setiap kota yang disinggahinya, selalu ia menyampaikan Injil, sehingga lahirlah petobat-petobat baru. Betapa pentingnya penginjilan ini dalam gereja, karena merupakan bentuk nyata dari pertumbuhan gereja secara kuantitas. Kemudian akan lebih bertumbuh lagi melalui pemuridan, sehingga menjadi dewasa dan kuat imannya.

\footnotetext{
${ }^{86}$ Yune Sun Park, Tafsiran Alkitab Kisah Para Rasul, (Batu: Departemen Literatur YPPII, n.d.), 274

${ }^{87}$ Warren W. Wiersbe, Berani di Dalam Kristus, (Bandung: Kalam Hidup, 2009), 80

${ }^{88}$ Ds. H.v.d. Brink, Kisah Para Rasul, (Jakarta: BPK Gunung Mulia, 1996), 304

${ }^{89}$ C. Van den Berg, Sungguh Merekalah Umat-Ku, (Jakarta: YKBK, 2011), 267
} 
Missio Ecclesiae, 7(2), Oktober 2018, 188-228

\section{Pendekatan}

Pendekatan misi yang dilakukan oleh Paulus adalah secara kontekstualisasi, yaitu menyesuaikan diri dengan adat setempat. Lima kali di dalam nats ini (1Kor. 19:19-23) menegaskan bahwa ia "menjadi seperti" suku atau golongan yang ingin dimenangkannya. Ia tidak menjadi sama dengan mereka, tetapi menjadi "seperti" mereka. Terhadap orang Yahudi ia berlaku seperti orang Yahudi, terhadap orang Yunani ia berlaku seperti orang Yunani, dan terhadap orang lemah ia berlaku seperti orang lemah. Rasul Paulus selalu menyesuaikan diri dengan konteksnya supaya pelayanannya tetap relevan.

Dalam pelayanannya kepada orang Yahudi, rasul Paulus belajar untuk patuh pada tata cara dan kebiasaan, dan adat istiadat orang Yahudi sejauh ia dapat melakukannya dengan hati nurani yang murni dan damai dalam hati (Rm. 9:3; 10:1). Kerinduan dan doanya untuk keselamatan mereka (Kis. 16:3; 18:8; 21:21;-27; 23:1-6). Sebagai contoh bahwa Paulus taat pada budaya adat-istiadat Yahudi adalah ketika ia membawa Timotius, ia menyunatkannya (Kis. 16:3). Sunat tidak menguntungkan bagi Timotius dan Paulus, tetapi ia memberi keuntungan yang besar dalam pelayanan mereka kepada orang-orang Yahudi, untuk memenangkan mereka bagi Tuhan.

Dalam pendekatannya kepada orang Yahudi, Paulus sendiri menunjukkan bahwa ia seringkali terlebih dulu membuat hubungan dengan sinagoge Yahudi di kota-kota Yunani yang dikunjunginya. Orang-orang Yahudi adalah salah satu mualafnya yang pertama, juga di Korintus (Kis. 18:8). Meskipun ia dilahirkan sebagai orang Yahudi, Paulus yang Kristen telah melakukan pemutusan total dengan Yudaisme dan Taurat sebagai dasarnya. Di dalam Kristus seseorang bukan lagi Yahudi atau Yunani (Gal. 3:28; Rom. 10:12; Kol. 3:11). ${ }^{90}$

Paulus melakukan hal ini (= menjadi seperti....) dengan satu maksud untuk dapat menarik semua lapisan masyarakat. Ia menyesuaikan diri dengan jiwa-jiwa yang dilayaninya. "Aku menjadi...", kata ini diterjemahkan dari kata kerja yang biasanya menunjukkan satu peristiwa tertentu di masa lalu. Meski demikian, mungkin juga maksud Paulus di sini lebih umum sifatnya. ${ }^{91}$ Ketika bertemu dengan orang Yahudi, maka Paulus menjadi seperti orang Yahudi.

Pelayanan pertama kepada orang Yahudi dan untuk itu Paulus taat dan patuh pada tata cara, kebiasaan dan adat orang Yahudi sejauh ia dapat melakukannya dengan hati nurani yang murni dan damai dalam hati (Rom. 9:3; 10:1). Kerinduan dan doanya untuk keselamatan mereka (Kis. 16:3; 18:8; 21:21-27; 23:1-6). Saat Paulus akan membawa Timotius dalam pelayanan, ia menyunatkannya (Kis. 16:3). Sunat tidak menguntungkan bagi Timotius maupun Paulus, tetapi ini memberi keuntungan yang besar dalam pelayanan mereka kepada orang-orang Yahudi, untuk memenangkan mereka bagi Tuhan. ${ }^{92}$ Perlu diketahui bahwa yang dimaksud "orang Yahudi" di sini

\footnotetext{
${ }^{90}$ V.C. Pfitzner, Kesatuan Dalam Kepelbagaian, (Jakarta: BPK Gunung Mulia, 2000), 166

${ }^{91}$ Paul Ellingworth \& Howard Hatton, Pedoman Penafsiran Alkitab Surat Paulus yang Pertama Kepada Jemaat di Korintus (Jakarta: LAI, 2010), 242

${ }^{92}$ David Ibrahim, Pelajaran Surat 1 Korintus, (Jakarta: Mimery Press, 1999), 141
} 
adalah orang-orang yang beragama Yahudi, bukan sekadar bangsa Yahudi. Pengertian ini didukung oleh ungkapan hukum Taurat atau hukum Musa. Dalam teks Yunani hanya dikatakan "hukum". Terjemahannya juga dapat menjadi hukum agama Yahudi. ${ }^{93}$

"Menjadi seperti...." berarti: hidup dengan cara seperti, atau bertingkah laku dengan cara. Dengan penjelasan arti kata ini menekankan bahwa Paulus mencoba melakukan pendekatan secara kontekstualisasi, dalam hal ini sesuai dengan budaya Yahudi.

Kebudayaan dan agama erat sekali hubungannya dan bahkan seringkali sangat sulit dipisahkan. Bagi para utusan Injil lintas budaya, harus sedia mempelajari kebudayaan masyarakat yang akan dilayani. Sebab memang tidak ada satu pun kebudayaan di dunia ini yang dapat dikemukakan sebagai contoh kebudayaan yang alkitabiah. Setiap kebudayaan bangsa yang diperhadapkan kepada Injil, pasti mengalami koreksi, penyucian dan perombakan. Setiap utusan Injil yang mengabaikan hal ini, bisa jatuh ke dalam sikap ekstrem. ${ }^{94}$ Misalnya dalam budaya Batak; ada seorang hamba Tuhan yang mengklaim bahwa budaya ulos itu dianggap berhala karena mengandung mistis dan magi. Sehingga gembala sidang setempat yang mayoritas jemaatnya orang Batak melarang memakai ulos.

Apakah benda (ulos) ini salah? Memang dalam awal pembuatan pertama ulos ini ada unsur mistisnya. Karena waktu menenunnya, ulos itu dicampur dengan darah manusia, supaya ulos itu berkarisma terhadap orang yang memakainya. Dalam istilah bahasa Batak disebut "martohonan". Si penenun berdoa dan memohon kepada Mulajadi Nabolon (nama dewata suku Batak) supaya ulos itu membawa ketenangan dan keteduhan bagi si pemakai. Namun pada masa sekarang ini, ulos sudah diproduksi dengan mesin sebagai peralatan yang modern.

Di ayat berikutnya, 1 Korintus 9:21, Paulus mengadakan pengakuan bahwa bagi orang-orang yang tidak hidup di bawah hukum Taurat aku menjadi seperti yang tidak hidup di bawah hukum Taurat, sekalipun aku tidak hidup di luar hukum Allah. Artinya, bahwa bagi Paulus, ada hal-hal yang ia tidak setuju dengan adat-istiadat Yahudi. Ia lebih taat pada hukum Allah. Namun, supaya kehadirannya dapat diterima, ia menjadi seperti..., yang menunjukkan pendekatan secara kontekstualisasi.

"Bagi orang yang tidak hidup di bawah hukum Taurat" (1Kor. 9:21). David Ibrahim memahaminya demikian, "Ini berbicara tentang orang-orang kafir yang tidak hidup di bawah hukum Musa (Rom. 2:12, 14-15). Jika Paulus datang kepada mereka, ia tidak membawa larangan-larangan, tetapi bukan berarti ia bertindak sesuka hati. Paulus tidak meminta mereka untuk melakukan Taurat, tetapi untuk percaya kepada pemberitaan Injil (Gal. 3:2; Kis. 17:28-34= orang Kristus hidup di bawah hukum kasih, Rm. 13:8; Gal. 5:13; 6:2). ${ }^{95}$

\footnotetext{
${ }^{93}$ Paul Ellingworth \& Howard Hatton..., 242

${ }^{94}$ Petrus Octavianus, Identitas Kebudayaan Asia Dalam Terang Firman Allah, (Batu: Yayasan Persekutuan Pengkabaran Injil Departemen Literatur, 1985), 33

${ }^{95}$ David Ibrahim, Pelajaran Surat 1 Korintus, (Jakarta: Mimery Press, 1999), 141
} 
Salah tujuan dari misi dalam pelayanan Paulus dengan pendekatan secara kontekstualisasi ini adalah supaya ia dapat memenangkan sebanyak mungkin orang kepada Kristus. Paulus telah menghambakan dirinya kepada semua orang dan menyamakan dirinya dengan mereka yang lemah, tetapi ia tidak pernah berkompromi atau merendahkan kedudukannya yang mulia itu dengan menuntut haknya. Dalam halhal yang tidak penting rasul Paulus mau mengalah, tetapi dalam hal yang penting ia mempertahankannya.

Brill mengatakan bahwa setiap kali rasul Paulus menaati sesuatu yang tertulis di dalam hukum Taurat, maka ia melakukannya karena ia suka berbuat demikian, dan bukan karena ia dipaksa berbuat demikian. Misalnya, pada waktu rasul Paulus menyunatkan Timotius. Ia melakukannya tanpa paksaan dari orang-orang Yahudi. Tetapi, ketika orang Yahudi menuntut supaya Titus disunatkan, Paulus menolaknya dengan tegas, karena ia telah bebas dari hukum Taurat. Tetapi itu tidak berarti bahwa ia tidak boleh melakukan apa yang dikatakan di dalam hukum Taurat. ${ }^{96}$

Apabila Paulus berkhotbah kepada orang-orang Yahudi, ia mulai dengan kehidupan nenek moyang dalam Perjanjian Lama. Tetapi, apabila ia berkhotbah kepada orang-orang bukan Yahudi, ia mulai dengan Allah Sang Pencipta. Paulus tidak memiliki persediaan khotbah untuk segala kesempatan. ${ }^{97}$ Demikian juga Yesus melakukan pendekatan yang sama. Kepada Nikdemus, seorang keturunan bangsawan Yahudi. Ia berbicara tentang kelahiran baru (Yoh. 3).

Paulus sebenarnya tidak kehilangan identitasnya. Kita tidak boleh kehilangan identitas diri dalam menjangkau orang lain. Paulus tidak menjadi seperti bunglon yang berubah-rubah warna mengikuti lingkungannya. Ia tetap dengan jelas mengerti siapa dirinya. Ada banyak pelayanan diakonia yang bersifat merangkul dan menyamakan diri dengan orang-orang yang dilayani. Tuhan juga memberi kita tanggung jawab untuk memberitakan Injil dalam kesaksian hidup dan perkataan. ${ }^{98}$

Perlu diingat bahwa budaya dan adat-istiadat itu adalah ciptaan manusia, yang ditetapkan untuk kelangsungan dan kelanggengan hidup dari kelompok tersebut. Karena ciptaan manusia, terkadang ada yang bertentangan dengan apa yang Tuhan firmankan. Tetapi ada juga yang sejalan dan sesuai dengan firman Allah. Itulah sebabnya dalam pendekatakan menyampaikan Injil itu dapat memakai budaya setempat sebagai sarana yang dapat menjembatani dalam pemberitaan Injil.

Niebuhr mencatat beberapa hal sehubungan dengan kebudayaan manusia, yaitu: Pertama, kebudayaan adalah warisan sosial yang mereka terima dan teruskan. Kedua, kebudayaan adalah hasil prestasi manusia. Ketiga, hasil-hasil prestasi manusia ini semuanya dirancang untuk satu atau beberapa tujuan akhir; dunia kebudayaan adalah dunia nilai-nilai. Keempat, nilai-nilai yang menjadi perhatian prestasi manusia ini secara domain adalah nilai-nilai untuk kebaikan bagi manusia. Kelima, perhatian harus

\footnotetext{
${ }^{96}$ J. Wesley Brill, Tafsiran Surat Korintus Pertama, (Bandung: LLB, 1998), 168

${ }^{97}$ Warren W. Wiersbe, Hikmat di Dalam Kristus, (Bandung: Kalam Hidup, n.d.), 128

${ }^{98}$ Billy Kristanto, Ajarlah Kami Bertumbuh, (Surabaya: Momentum, 2006), 140
} 
ditujukan kepada kemajemukan yang menjadi ciri dari semua kebudayaan. ${ }^{99}$ Yang harus diingat di sini adalah bahwa Kristus harus di atas budaya. Artinya, budaya yang bertentangan dengan Injil harus ditolak.

\section{Tolok Ukur}

Yang tidak boleh dilupakan dalam pendekatan secara kontekstualisasi adalah tolok ukurnya ialah firman Allah. Walaupun pendekatan Paulus luwes sekali, namun ia memiliki suatu tolok ukur. Ia peka terhadap kebudayaan, tetapi tunduk kepada firman Allah. Sekalipun ia menyesuaikan diri dengan kebudayaan setempat, ia tetap hidup di bawah hukum Kristus. Hukum Kristus, firman Allah, merupakan tolok ukur baginya. Firman Allah adalah wewenang tertingginya. Meskipun ia harus menyesuaikan diri, ia juga menguji segala sesuatu dengan firman Allah supaya Injil yang disampaikan itu tetap murni. ${ }^{100}$

Untuk itu, diperlukan akan pengajaran firman Allah yang lebih matang kepada jiwa-jiwa yang sudah dijangkau itu, supaya dapat bertumbuh dan berakar, yang akhirnya menghasilkan buah. Dalam pelayanan misi, mau tidak mau, pemberitaan firman (khotbah) atau pengajaran itu sangat penting, khususnya bagi petobat-petobat baru.

Dalam Alkitab, panggilan untuk terlibat dalam pelayanan misi kota bermula dari nabi Yunus dan perintah Tuhan untuk pergi ke Niniwe dan mengabarkan Firman Tuhan di sana (Yun. 1:2; 3:2). Alkitab menyebutkan bahwa Niniwe adalah sebuah kota megah (Yun. 1:2). Berkat Tuhan dicurahkan secara melimpah di Niniwe. Kota ini tidak hanya merupakan kota metropolitan besar - ibukota dari kekaisaran yang kuat, namun kota ini juga terkenal karena keindahannya.

Banyak orang menganggap Niniwe sebagai kota terindah yang pernah dibangun di bumi ini. Secara militer, Niniwe tampaknya tak terkalahkan. Menurut kabar, setidaknya pada zaman dahulu, kota ini membangun benteng pertahanan di luar kota yang membentang sepanjang 60 mil dan di dalam kota dibangun tembok-tembok setinggi 100 kaki. Kereta kuda berjajar tiga dapat melintas di atas benteng yang dibangun. Untuk membangun istana raja di Niniwe dibutuhkan 10.000 budak selama 12 tahun. Tamantaman kota dan bangunan-bangunan umum lainnya sangat tersohor di dunia. Niniwe telah berdiri selama 1500 tahun, yang membuat kebanyakan kota besar lainnya tampak seperti baru berkembang. Niniwe benar-benar adalah kota megah. Niniwe yang disebutkan dalam Alkitab juga mewakili atau menjadi simbol kota pada zaman kuno dan modern. Niniwe adalah kota berbudaya sekaligus kota yang penuh ketidakadilan, penindasan, dan kekerasan. Kejahatan kota inilah yang dikatakan Allah sebagai masalah utamanya dan menjadi alasan mengapa pelayanan misi Yunus sangat diperlukan (Yun. $1: 2) .^{101}$

${ }^{99}$ H. Richard Niebuhr, Kristus dan Kebudayaan, (Jakarta: Petra Jaya, n.d.), 37-43

${ }^{100}$ Budiman R.L., Pelayanan Lintas Budaya \& Kontekstualisasi..., 8-9

101 Panggilan Bagi Pelayanan Misi Kota. Sumber: http://misi.sabda.org/panggilan_bagi_pelayanan_misi_kota (diakses 3 Nopember 2017) 
Allah mengutus Yunus ke sana untuk menyampaikan pesan Allah, di mana warga Niniwe dituntut untuk hidup dalam pertobatan. Yunus hanya mengkhotbahkan tentang pertobatan. Berkat khotbahnya ini, akhirnya penduduk Niniwe diselamatkan dari hukuman dan murka Allah.

\section{Kesimpulan}

Model Misi Perkotaan yang dilakukan oleh rasul Paulus di Korintus menjadi suatu bentuk pelayanan misi, yang kontekstual. Adapun bentuk model misi perkotaan yang dilakukan Paulus adalah "menjadi seperti". Dengan menjadi seperti, memudahkan dalam pendekatan untuk menyampaikan kabar baik. Tetapi patut diperhatikan dan digarisbawahi, bahwa dalam model pendekatan ini jangan sampai kebablasan, yaitu kehilangan kontrol diri. Ada rambu-rambu yang harus diperhatian, di mana firman Allah adalah sebagai tolok ukur. Dan tujuan dari pelaksanaan model misi ini adalah memenangkan sebanyak mungkin jiwa-jiwa bagi kemuliaan nama Tuhan. Untuk terwujudnya akan hal ini, maka makna dari "menjadi seperti" dapat pula berarti bahwa umat Krisrtus dapat menjadi teladan, sebagai kesaksian yang hidup bagi orang lain.

Pelayanan misi perkotaan harus menjadi perhatian gereja. Karena di perkotaan itu terdapat multikompleks permasalahan. Yang paling menyolok adalah adanya kesenjangan sosial, yang membuat orang lain enggan dekat dengan gereja. Belum lagi keegosian, yang mementingkan kepentingan pribadi, membuat ketidak-pedulian dengan sesama. Tetapi dengan konsep yang dilakukan Paulus, yaitu "menjadi seperti", dapat menciptakan keterbukaan dengan orang lain. Di sinilah kesempatan untuk dapat menjadi saksi. Yang tidak kalah penting dalam pendekatan secara kontekstualisasi ini adalah bahwa firman Allah menjadi barometernya. Jangan sampai firman Allah yang menyesuaikan diri dengan budaya. Dengan menjadi seperti, bisa saling memahami, dan berempati, yang tentunya dilandasi dalam kasih Kristus, sehingga bisa menjadi berkat bagi orang lain. 